\title{
واسط اول مدينة مدورة في الاسلام دراسة تاريفية في شكل المدينة وبنائها.
}

Wasit is the first city in Islam to study the historical form of the city and its construction.

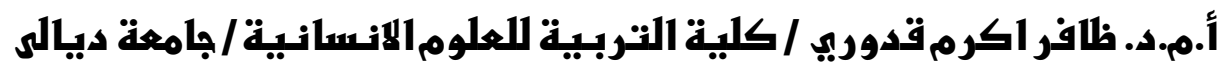

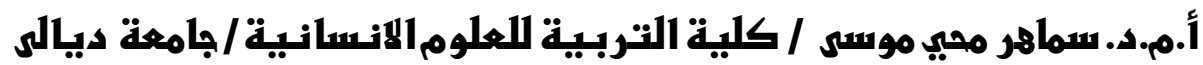

\begin{abstract}
unit|
أحدى ابرز وأهم مدن العراق في العصر الأموي ، لما لعبتهُ من دور في الأحداث التاريخية ، ابان تللك الفترة من الزمن ، بنيت على شكل دائري و لا نبالغ بالقول أنها المدينة الأولى التي تبنى بالعر اق يشطر ها نهر دجلة الى نصفين وبذللك كانت قد سبقت مدينة بغداد المدورة ، وقد ر اعى القائمون على بنائها مسألة الحصانة والجانب العسكري فيها بشكل كبير حيث بنى فيها أثر من سور فكان نهر دجلة هو المزود للمدينة بالمياه والذي يشطر ها الى نصفين يربط بينهما جسر يستخدم للعبور وكان البناء بالثكل المدور قد وفر وبشكل كبير أمكانية الدفاع عن المدينة كماوفر حماية للساكنين فيها ، وقد أثبتت الايام مدى فاعلية تلك المدينة وقوة حصانتها حين صمدت بوجه العباسيين لمدة سنتين من الزمن ، وكان لتلك الاهمية أن أندفع ابن بحشل للكتابة عنها و افرد مؤلفا بعنوان ناريخ

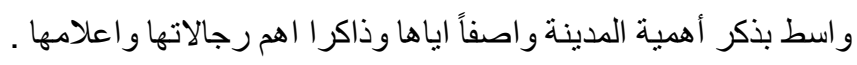

\section{ABSTRACT}

One of the most prominent and most important cities of Iraq in the Umayyad era, because of its role in historical events, during that period of time, built in circular form and do not exaggerate by saying that it is the first city built in Iraq divided by the Tigris River to two halves and thus preceded the city of Baghdad, The construction of the Tigris River is the water supply to the city, which is divided into two halves, which are connected by a bridge that is used for crossing. The building in the round shape provided a great possibility for the defense of the city and provided protection for the inhabitants. Has been proven The days of the effectiveness of the city and the strength of its immunity when it resisted the Abbasids for two years, and it was important that the son of Bshail to write about it and author of the book entitled Wasit history to mention the importance of the city, describing it and the most prominent of its men and flags.

الإقدمية

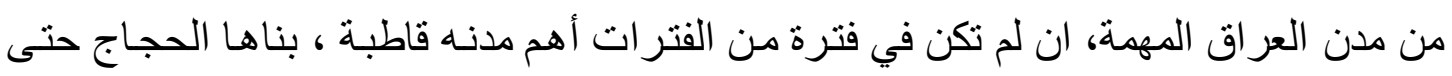

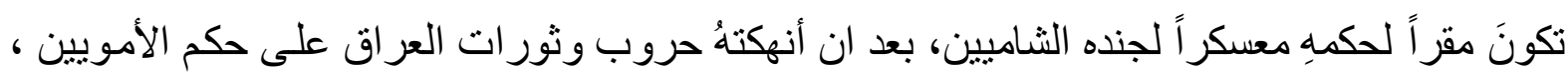

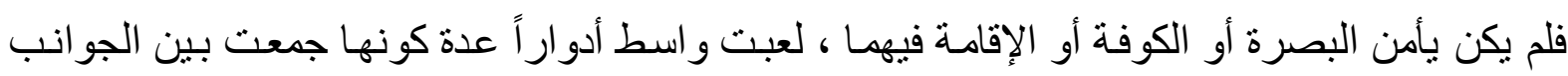

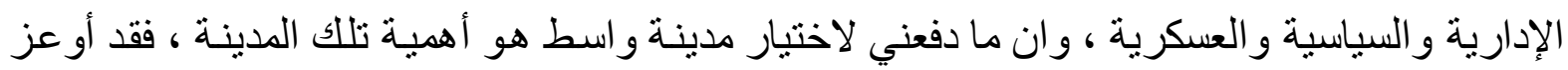

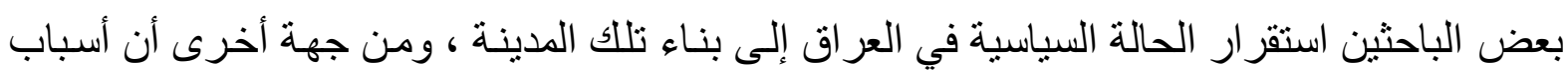

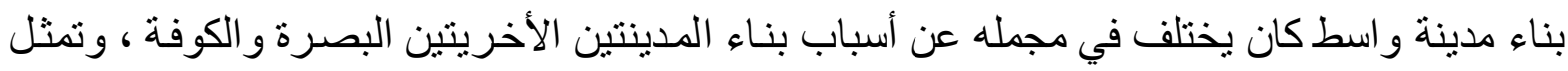

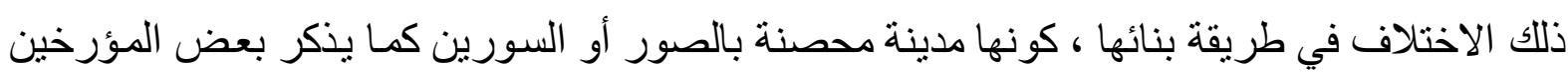

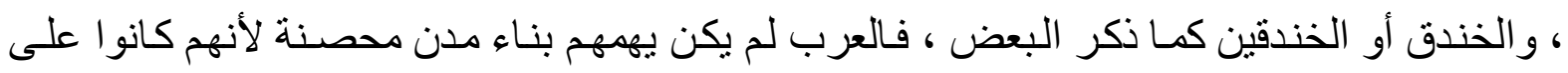

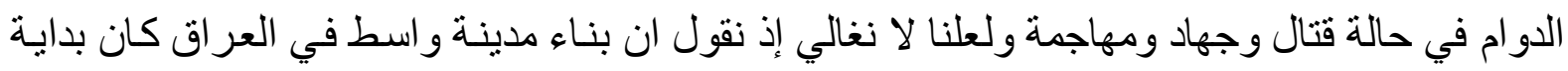


للتفكير في بنـاء مدن محصنة يكون غرضها إداريـاً ويجمع إلى ذلك الحصـانة و الميزة العسكرية إلى جانب كونها ضمن جو انب أخرى تطرق لها هذا البحث .

ولقد بقيت واسط حتى بعد وفاة مؤسسها الحجـاج تؤدي أغر اضـاً مهمـة وبقيت حصـانتها حتى عشر ات السنين وتطورت من مدينة إدارية إلى مدينة ضمت بطياتها عو امل أخرى كالتجارة و الزر اعة ولم تضمحل أو ينتهي دور ها ، وهو مـا يدلل على أهمية موقعها ودقة وصحة الاختيار ، لقد تم تقسيم

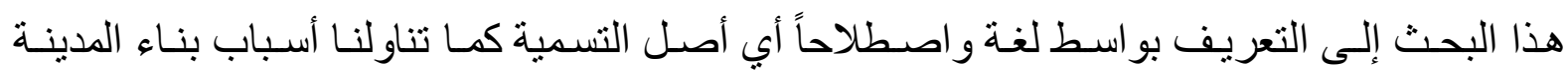
وخططها التي ضمت الأسوار و الخندق و القصر و المسجد الجامع و أهم وأبرز عو امل وجو انب مدينة و اسط.

- واسط لغفة :-

في اللغة هي "وسط الثيء ما بين طرفيه ، قال إذا رحلت فاجعلوني وسطاً أني كبير لا أطلق العندا ، أي أجعلوني وسطاً لكم ترفقون بي وتحفظونني"( ') . و الوسط محركة من كل شيء "أعدله"(r) ،

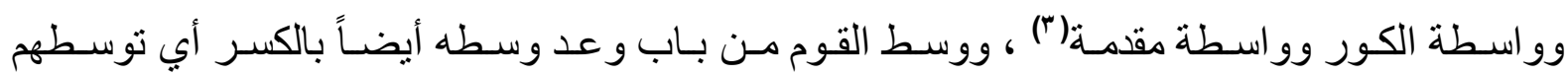
و الأصبع الوسطى معروفة والتوسيط ان يجعل الثـيء في الوسطو التوسيط أيضـاً قطع الثـيء صفين و التوسط بين النـاس من الوسـاطة والوسط من كل شيء أعدله وشيء وسط أيضـاً بين الردي والجيد و الجو هرة الفاخرة توضع في وسط القلادة(؛)، وجمع الكلمة أو اسط ، وحكي عن ثعلب ان وسط الثـيء بالفتح إذا كان مصمتاً فإذا كان أجز اء مخلخلة فهو وسط بالاسكان لا غير وو اسطه كوسطه (0) . - واسط التسمية :رغم ان هنالك اختلافاً في أصل التسمية ، إلا ان هناك آر اء أرجح من غيرهـا هي أقرب إلى

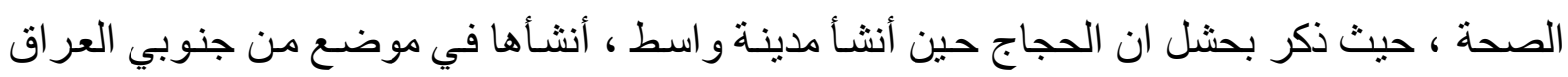
"يتوسط بين الكوفة و العراق"(") ، وذُكر أيضاً أنها سميت بواسط "بالقصر الذي بناه الحجاج بين الكوفة و البصرة"(v) ، وربما يكون ذلك القصر توسط المدينة ، دار جمع صساحب المنتظم سبب التسمية لقول الحجاج "هذا وسط ما بين المصريين الكوفة والبصرة"(^) ، كذلك ذكر الذهبي أن تسميتها جاءت لأنها "وسط مـا بين الكوفة و البصرة" ، ومن خلال تللك الروايات ، يبدو ان و اسط استمدت تسميتها كونها وسطاً بين أهم مصرين في العراق آنذاك الكوفة و البصرة ، حيث ذُكر أنها كانت وسطاً بين ثناث مواقع البصرة و الكوفة و لأهو از ، حيث ذكر أنسُ بين و اسط وبغداد ثماني مر احل وبين واسط و البصرة سبع مر احل و إلى مدينة الكوفة ست مر احل(9) ، وذُكر أيضاً ان الحجاج سار إلى قرية فوق و اسط بيسير يقال لها و اسط القصب فبات بها واستطاب ليلها واستعذب أنهار ها و استمر أ طعامها وشر ابها فقال "كم بين هذا الموضع و الكوفة فقيل لهُ أربعون فرسخاً قال فإلى المدائن قالو أربعون فرسخاً قال فإلى الأهواز 
قالو ا أربعون فرسخاً قال فإلى البصرة قال أربعون فرسخاً قال هذا موضع متوسط" ( ") ، فكانت و اسط

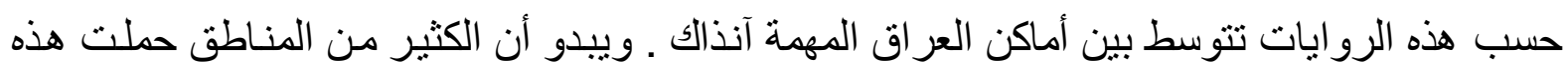

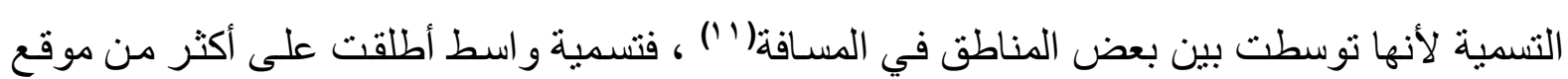

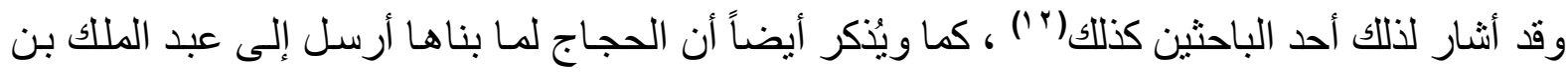

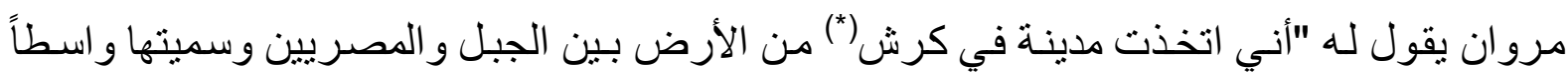

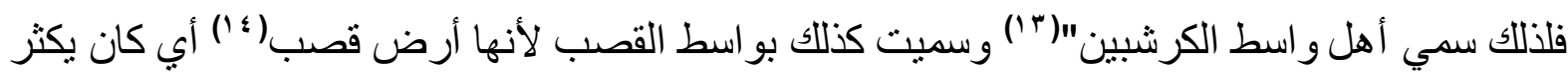

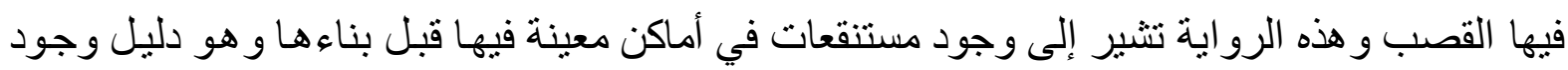
بعض البطائح .

\section{- أسباب بناء واختيار مدينة واسط (الاختلاف في ثاريخ بنائها) :-}

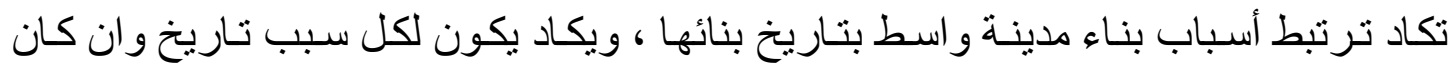

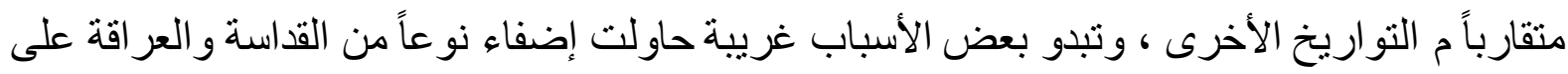

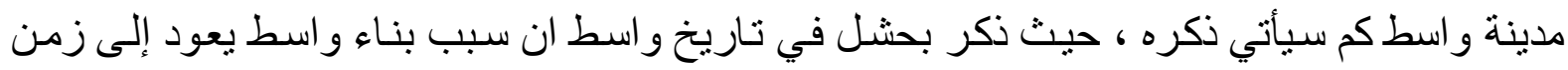
بختنصر عندما خرب بيت المقس فبكت الأرضون "وكانت كسكر أكثر ها بكاءً . فأوحى الله تعالى وعز

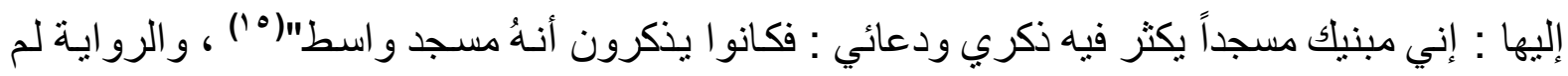

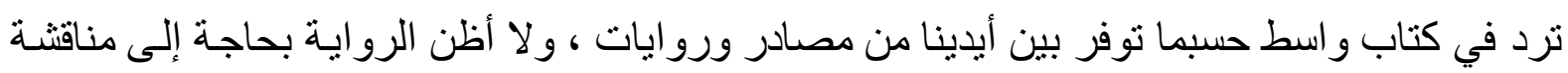

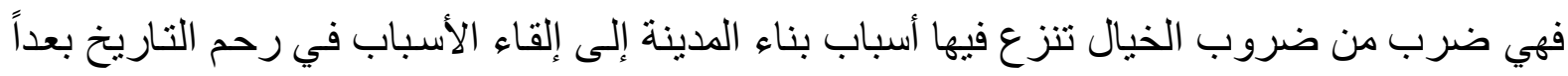

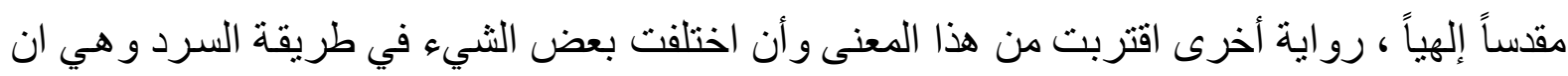

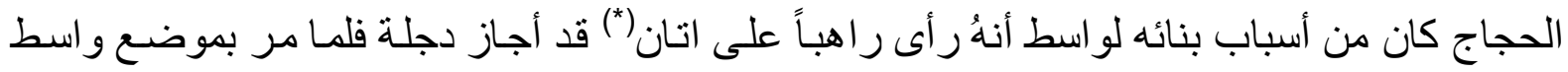

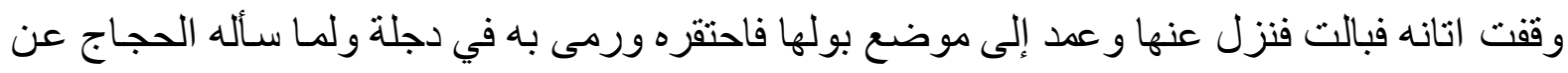

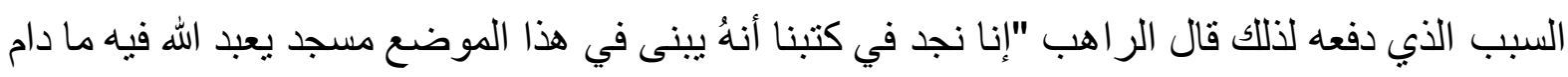

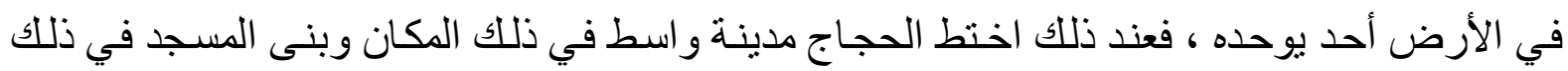

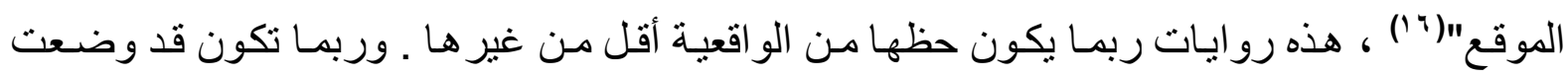

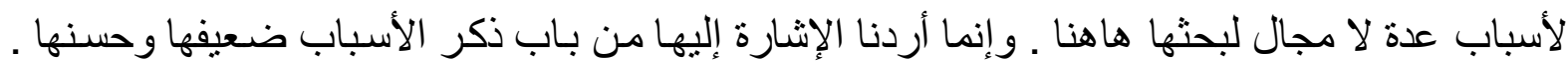
يُّكر كذلك ان عبد الملك بن مروان حين بعث الحجاج بن يوسف ليتولى إدارة العر اق نزل أولاً مدينة

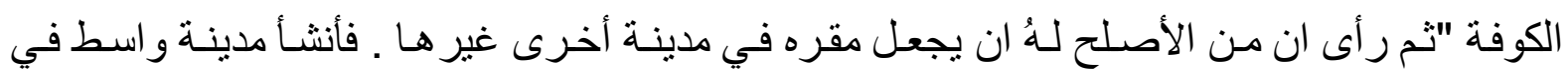

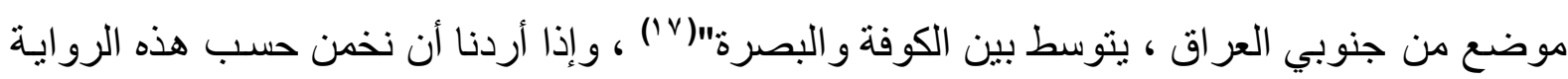

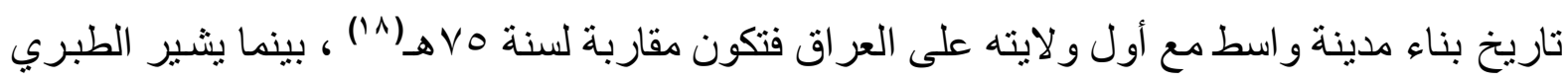

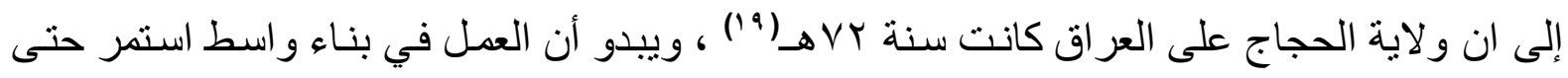




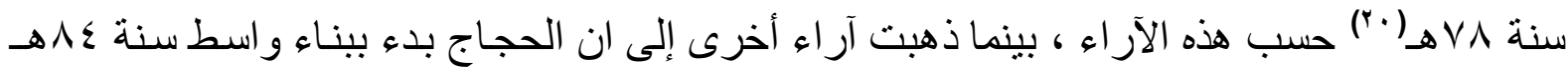

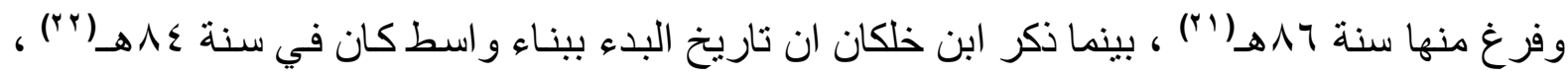
ورغم اختلاف الروايات التاريخية ، والتي تحصر عملية البناء بين سني الـه هـ و الــدهـ ، فان أحد الباحثين أشتار وبالاستناد إلى كتاب تـاريخ و اسط من ان الحجاج فكر في بنـاء مدينـة واسط بعد قضـائه

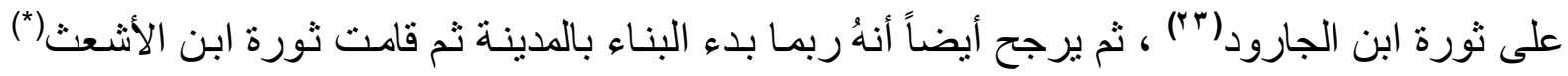
ويرجح تبعا لذلك بناء و اسط سنة ائهـ ، ويذكر بحثّل ان عبد الملك حين أقر الحجاج على العراق قدم من الحجاز سنة ب Vه فأقام بالكوفة سنة ثم ولي عليها يزيد بن أبي كبشـة ، ثم انحدر إلى البصرة فأقام بها سنة "فقال اتخذ مدينة بين المصرين أكون بـالقرب منهما ـ أخاف أن يحدث في إحدى المصرين حدث و أنا في المصر الآخر فمر بواسط فأعجبته فقال هذا واسط المصرين فكتب إلى عبد الملك بن مرو ان يستأذنه في بناء مدينة بين المصرين"( ؛ r) ، و إذا ما أردنا الأخذ بهذه الرو اية فإن بناء و اسط كان بعد سنتين أو أكثر بقليل من قدوم الحجاج والياً إلى العراق ، و هو يرجح سبب البنـاء فيما رآه الحجاج من ثور ات خرجت على الحكم الأموي من جهة ـ وحاجته إلى مدينة حصينة وبعيدة متوسطة بين مدن العر اق الرئيسة آنذاك من جهة أخرى ـ و هو مـا يفسر أيضاً إجر اءات الحجاج الأمنية في مدينة واسط من إخر اجِه كل نبطي بها وقال "لا يدخلون مدينتي فأنهم مفسدة"(ro) ، أما قصة الأموال التي بعثها عبد الملك للحجاج لثر اء موقع واسط وبنـاء المدينـة ، والتي ذكر أنها كانت تعادل خراج العراق كله لمدة خمس سنين و هو ما يشير إلى حجم ما صرف من أمو ال على بناء المدينة ، يضاف أن أمر تلك الأمو ال مع ما صرف على ثورة ابن الأشعث جعل آراء الباحثين تربط على ما يبدو بناء المدينة في تلك السنة لأن مخاطبـة الحجـاج لعبد الملك في أمـر البنـاءو الإنفاق على حرب ابن الأشعث جـاء منز امنـاً "إني

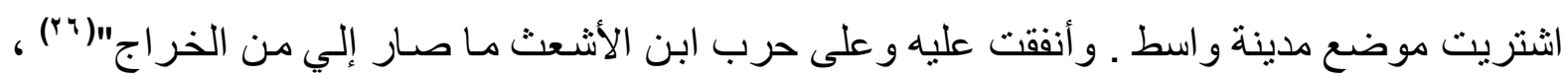
ويبدو أنها كانـت بعد بنـاء مدينـة و اسط ، وحدوث ثورة ابـن الأشـعث إذا أردنـا التسليم بمـا أثـار إليـه

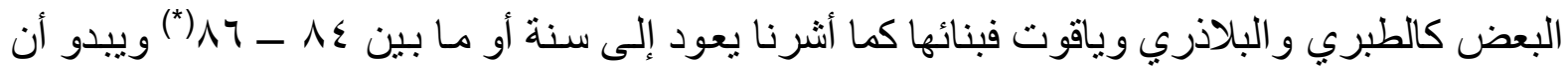

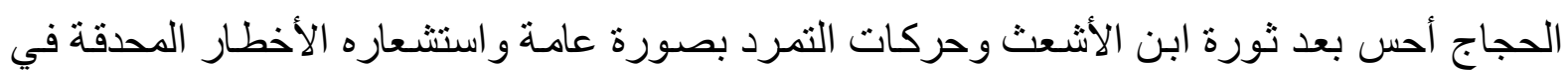
إقامته في العر اق بتلك الأحو ال القلقة ، وكثرة التجارب التي خاضـها متمثلة بثور ات وحركات ضـ الأمويين كثورة عبد الله بن الجارود وابن الأشعث ومهاجمة الزنج الذين استغلوا انشـال الحجـاج بثورة

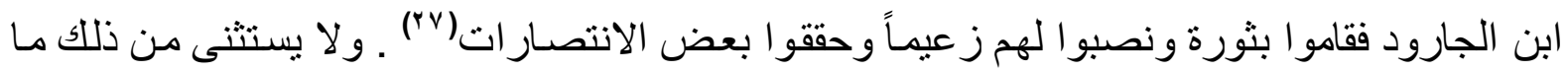
قام به الخوارج الأز ارقة بقيادة قطري بن الفجاءة وقد هاجم هؤلاء الكوفة وقتلوا و اليها وكان ذلك سنة ه Vهـ(^^) . و اجه كذللك الحجاج وفي السنة ذاتها إحدى أقوى حركات الخوارج التي قادها شبيب بن بزيد

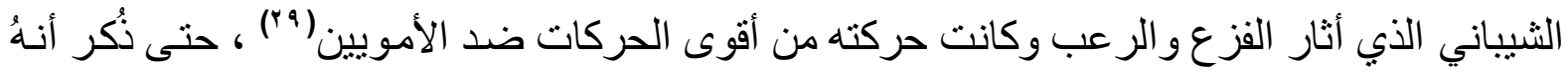
قتل من أصحاب الحجاج أربعة وعشرين أمير اً كلهم أمراء الجيوش(·") ـ ويبدو أن الحجاج أحس بعد الحد 
تلك الحركات و الثور ات المعارضة بضرورة اتخاذ مدينـة تكون مقراً للهُ ولجنده ويضمن فيها قدراً من الحيادية( آ) . وسنأتي على ذكر أمور أخرى بهذا الخصوص ـ أما طريقة اختيار موقع المدينـة ، فيُذكر

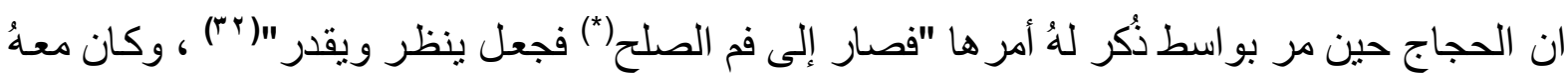
أحد الدهاقين فأخبره بقصة كسرى وما حدث في هذا الموقع (*). ويبدو من تلك الروايـة أن أمر اختبار الحجاج لتلك المنطقة (و اسط) لم يكن مرتجلاً و أنهُ كان معهُ من يشير عليه بالاختيار وهو ما توضسح في

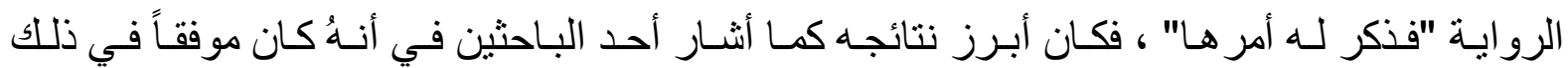
الاختيار (r)

\section{- وصف مشينة واسط (خطط واسط) وما هولها :-}

يبدو ان مدينة واسط كانت تنقسم إلى نصفين أو إلى مدينتين ، يفصل بينهما نصر دجلة ، فالتي في الجانب الثرقي من دجلة هي المدينة القديمة ، وقد بنى الحجاج واسط في الجانب الغربي ووصل بين المدينتين بجسر صنعهُ من السفن(؛")" ، وذكر بحشل ان الحجاج اشترى موقع واسط من رجل من أهل داوردان(") بعث إلبه و اشتر اها منهُ بعشرة ألاف در هم "فأقام فيها و أمر بالبناء فبنى القصر و المسجد و السورية ، وحفر الخندق في ثنلاث سنين"(ro) ، فكانت تلك الأبنية على مـا يبدو النواة الأولى لمدينة و واسط ، وتبين الأمو ال التي أنفقت على بنائها كما ذكرنـا الفخامـة وحجم التحصين الذي أر ادهُ الحجـاج لمدينتهُ حتى ذُكر أنهُ أنفق على بناء قصره و الجامع "و الخندقين والسور ثنلاثة وأربعين ألف ألف در هم فقال له كاتبه صالح بن عبد الرحمن هذه نفقة كثيرة وان احتسبها للك أمير المؤمنين وجد في نفسه قال فما نصنع قال الحروب لها أجمل فاحتسب منها في الحروب بأربعة وثلاثين ألف ألف در هم ، واحتسب

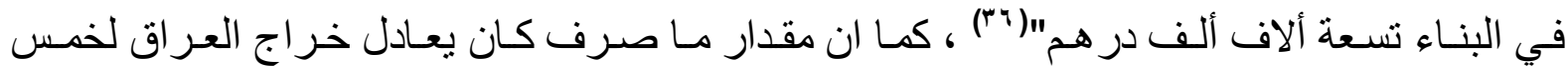
سنين( آr) ، و يبدو من النص أعلاه ان هناك تلاعباً من قبل الكاتب صالح بن عبد الرحمن فقد أشنار على الحجاج بأن لا بذكر كل المصروفات فقط في عملية البناء و إنما أن يوزع تلك الأموال من خلال ذكر مـا أنققه على الحروب و التورات وهو ما ذكرناه فيما سبق من البحث وكيف ان بحشل ذكر ان الحجاج ذكر لعبد الملك ان تلك الأموال أنفقت ليس في باب البناء فقط وإنما في مجال القضاء على الثور ات وحركات المعارضة .

وقد وصفت بأنها "سهلية جبلية برية بحرية يوجد بها الرطب و الثلج و القمح و السمك"(^") . وقد حفر الحجاج لمدينته هذه الأنهار من نهر الزاب الأسفل(9") وحفر منها نهري النيل و الز ابي وسماه زابيا لأخذه من الز ابي القديم" ، و أحيا مـا على هذين النهرين من الأرضين ، و أحدث المدينـة التي تعرف

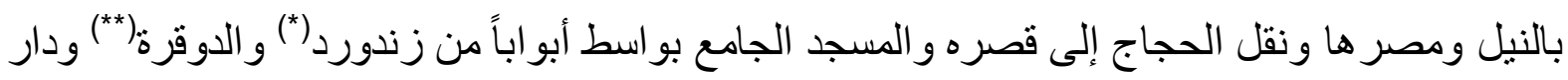
وساط ودير ماسر (*) حسان وشر ايط فضج أهل هذه المدن ، وقالو ا قد أومنا على مدننا و أمو النا فلم يلتقت 
إلى قولهم"( •) ، أما قصر الحجاج الذي بناه فكانت لهُ قبة خضر اء(** شاهقة ذُكر أنها كانت تشـاهد من

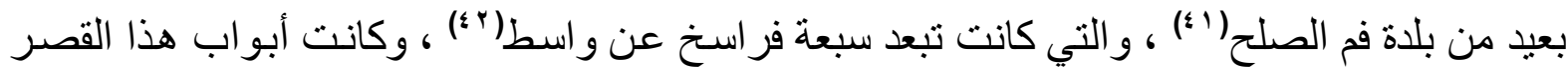

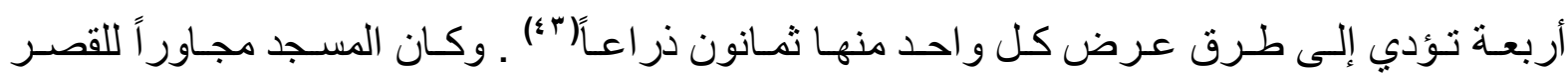
ومسـاحته مائتـا ذراع في مثلها وجعل على مقربـة من القصـر سوقاً عـامرة فيها تجار كل صنف مـن البضاعة يتعاطون تجارتهم في قطعة خاصة منها ، وكانت هذه السوق من الوسع بحيث اقتضت أرضـاً تمتد من القصر إلى شاطئ دجلة شرقاً ؛ ؛) ـ. أما الجسر الذي أشرنا إلبهه سـابقاً والذي يربط شطر مدينة و واسط فكان طولـه . ـا ذر اع(0 ؛) ،وكانـت المدينـة الغربيـة مـن و اسط تسـى كسكر و هـي مـن بنيـان

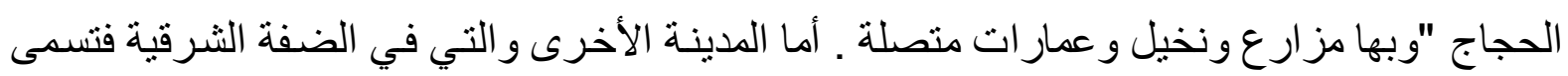
و اسط العر اق ، و هي أيضاً مثل أختها حسنة البناء فسيحة الأرجاء مبانيها سامية ... وبساتينها و أمو الها كثيرة ... وليس بها بطائح و أرضها واسعة وطينتها ممتدة و هو اؤ ها أصسح من هو اء البصرة وهي من

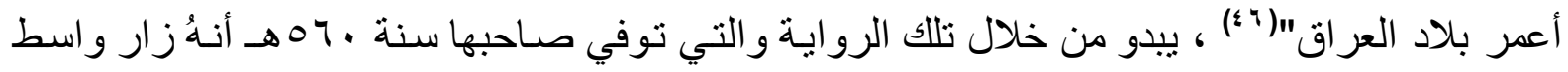
قبل ذلك التاريخ و هو بعيد عن سنة البناء لكن الجو والتربة ومناخ المنطقة قريب الثبه ، و هو يذكر ان كسكر هي التي بنيت أولاً ، وان المدينتين قد أصبحتا في عصره مـا جعلهُ يسهب في وصفها ، وقد وصـف أحد البـاحثين مدينـة واسـط بأنهـا أرض مسـتوية كثيرة الانغدـار بميـاه الفيضـان التي تؤلـف مستنقعات وأهو ار مؤقتة أو دائمية تسـاعد على تبديل الأنهار لمجاريها ، و هي قليلة الانحدار وتربتها غرينية رخوة خالية من الصخور (v؛) أمسا الدكتور العلي فيذكر أن أرض و اسط ليست مستوية استو اءً تامـاً إذ ان فيها بعض المرتفعـات و الوهـاد ، و هـي عرضـة للتبدل بفضـل الترسبات التي يكونهـا طمن الأنهار وخاصة أثناء الفيضانات(؛^؛)

وكانت المدينة تضم رحبات و اسعة منها رحبة قريبة من السوق في جنوبها ومساحتها ثلاثمائة ذر اع في مثلها ، و الثانية مساحتها مائتا ذر اع في مائـة ولعلها كانت في أقصى المدينـة و الثالثة مسـاحتها

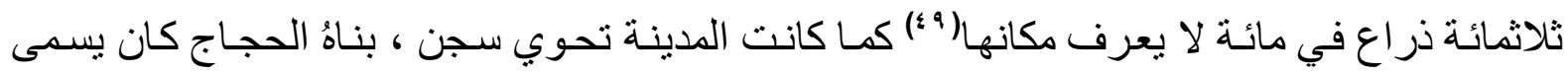
بالديماس( • () ، وقيل أنهُ سمي بالديماس لظلمته علسالتشبيه(10) ، ويبدو أن الخندقين و السور اللذان أحاطا

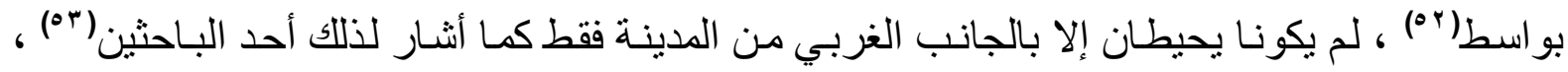
وزيادة في الاحتراز ، ومحاولة الحجاج في عزل جندهِ الثـاميين عن أهل العراق ، فقد ذكر بحثـل ان الحجاج كان "لا يدع أحداً من أهل المو اد يسكن واسط"( ؛) ، من جهة ولا يدع أحداً من أهل السواد

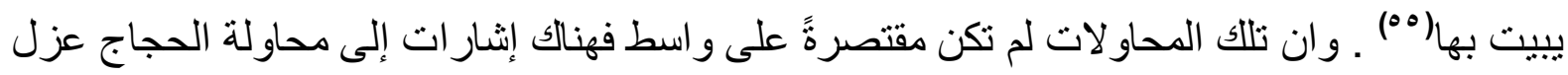
جنده الثـاميين عندما كان ينزل البصرة والكوفة(†ه) ـ ويرى الدكتور عبد الجبار ان تلك التحصينات

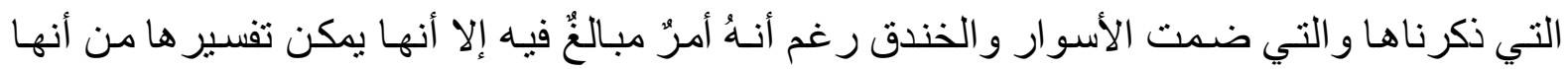


اتخذت لعرقلـة أو منـع هجرة أهـل السو اد إلى مدينـة واسط، وربمـا إنها كانـت تمثنل مخاوفـاً سياسـية و عسكرية لدى الحجاج من أي هجوم مباغت من أهالي البصرة أو أهالي الكوفة وذللك لعدم ثقته بهم، أو

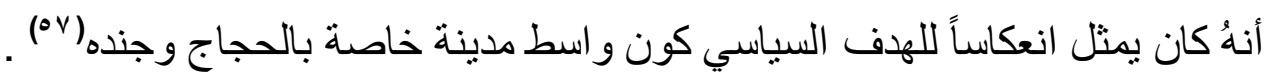

\section{- العواهل التي أدت إلى بناء واسط :-}

لابد وان هناك عو امل أدت إلى بناء مدينة واسط ، وقد اتفق بعض الباحثين واستناداً إلى بعض

الروايات واستقر اء الوقائع والأحداث التاريخية إلى تقسيم تللك العو امل إلى عو امل سياسية و عسكرية ،

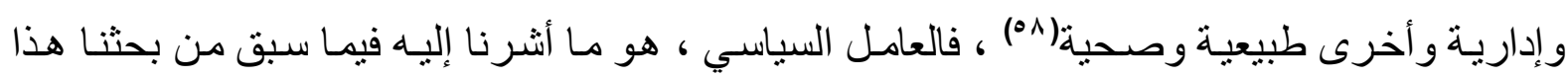
و الذي تمثل في ثور ات وحركات خرجت على الحكم الأموي ، فأصبحت مناطق العراق بأثر ها غير

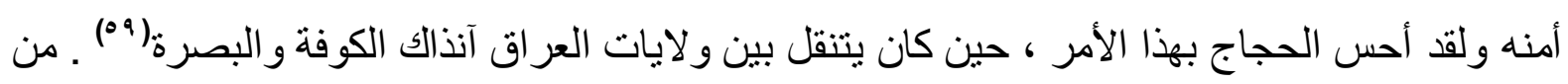
جهة و التي أثبتت للحجاج أهمية وجود مدينة غير هاتين المدينتين. فاختار واسط كما ذكرنا لتوسطها ، ثم حصنها بالسور و الخندق وفرض حظر اً للتجو ال الليلي فيها · ") ، كما أن أبو اب المدينة ، و التي كانت محروسة من قبل مجموعة من الحرس كانت تغلق عند المغرب ، بعد ان برجـع أهـالي المدينـة ويخرج من كان بداخلها من الغرباء('") ز و هذا بالطبع يشير إلى ضرورة مر اعاة الاحتياطات الأمنية القصوى . كما أن أحدى الروايات كانت تفيد أن دخول واسط كان يتم بأخذ موافقة الحجاج بالنسبة لمن يفد عليه "نزل جرير على عنبة بن سعيد بو اسطولم يكن أحد يدخلها إلا بأذن الحجاج فلما دخل على عنبة قال لهُ ويحك لقد غررت بنفسك فما حملك على مـا فعلت قال شعر قلته اعتلج في صدري وجاثـت بـه نفسي وأحببت ان بسمعهُ الأمير قال فعنفه و أدخلهُ بيتاً في جانب داره وقال لا تطلعن رأسك حتى ننظر كيف تكون الحيلة للك"(rי) ، ثم أورد القصة حول احتيالهِ على الحجاج وسؤال الحجاج لهذا الضيف الذي دخل المدينة دون إذن بالقول "ما أقدك علينا بغير إذننا"(rا) ـ و هذا يشير إلى شدة الإجر اءات الأمنية ـ أمسا موقعها بين البصرة والكوفة فيقول عنهُ المعاضيدي أنهُوفر هدوء الحالة السياسية في العراق والحيلولة لدية دون التمرد و الخروج على السلطة(؛ ج).

أما العامل الآخر وهو الأهم في تأسيس المدينة فهو العامل أو الجانب الإداري ، وقد أشـار أحد الباحثين لأمر مهم في بناء المدينة العربية بصورة عامـة بالقول "ازداد أثر العامل السياسي و الإداري بعد توسع الدولة العربية الإسلامية حيث أصبح لعامل وحدة الأمة والسيطرة على ربوع الدولة أثر بـالغ الأهمية خاصة وان المساحة الجغر افية قد اتسعت كثيراً ... و وان هذا العامل هو الذي يفسر عملية نقل العاصمة في أكثر مـن حـال ... مـن أجلـ تحقيق وحدة الأمـة وزيـادة السيطرة وضبط الأمسور فقد بـدأ الاتجاه نحو اختيار مو اقع مركزية وليس الإبقاء على المو اقع الهامشية(70)، وقد أشنرنا إلى أن الحجـاج حين أتخذ واسط قال عنها "هذا واسط مـا بين المصرين الكوفة والبصرة وكان كتب إلى عبد الملك 
يستأذنهُ في بناء مدينة بين المصرين فأذن له"(r7) ـو وهي رواية تبين أهمية الجانب الإداري أو العامل الإداري في بنـاء المدينـة وتوضـح الحاجـة لإدارة أعمال العراق وكيف كان الحجاج يتنقل بين الكوفـة و البصرة ويترك ن ينسب عنها عند مغادرة إحدى المدينتين(VV) ، كذللك فإن بحشل أورد روايـة في قول الحجاج "أتخذ مدينة بين المصرين أكون بالقرب منهما أخاف ان بحدث في إحدى المصرين حدث و أنـا في المصر آخر فمر بواسط القصب فأعجبته فقال هذا واسط المصرين"(^^) ــ وتبدو الروايـة أدق من الن رواية ابن الجوزي ، ويتضـح غرض الحجاج الإداري مضـافاً إلى أهداف أخرى ـ كما أورد البلاذري رواية بهذا الخصوص وكيف ان الحجاج كان يتنقل بجنده الثاميين فلما وصل إلى موقع و اسط ابتنى به مسجداً وقال "هذا مكان و اسط"(99") . كما أن موضع المدينة يتيح للحجاج إنقاذ جيشـه إلى أيـة جهة يريد و إلى أية مدينة تقع إلى المشرق من العراق تخرج عن طاعة الأمويين وتهدد كيانهم في المشرق(·") ، و هكذا اختير موضـع و اسط ليكون مقراً لحكم الحجـاج وتـؤمن منـه السيطرة الكاملـة والإشـر اف على إلى أعمال سكانها و أعمال نائبيه في البصرة و الكوفة( (v) . . و أصبحت مدينـة و اسط مركز اً للإشر اف على

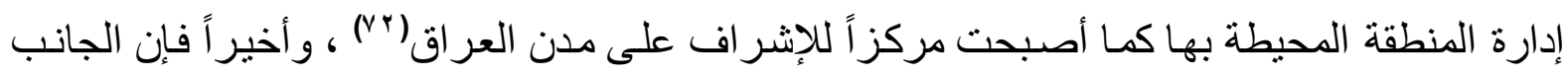
الإداري كان يتضح من خلال تخطيط المحلات والتي لم يكن فيها تقسيم واضح أو دور كبير للقبائل كما كان في المدن الأخرى التي أسسـها العرب كالكوفة والبصـرة والفسطاط ، ويتضـح دور مدينـة واسط الإداري أكثر من خلال ما أوضحه الدكتور عبد الجبار بـالقول أن المصرين البصرة والكوفة كانا قد اتخذا لأسباب عسكرية ولتسهيل مهمة الإمداد المادي و البشري للجيوش المقاتلة ... وظلت مدينة و اسط . أبان فترة الحجاج لا تقوم إلا بوظيفة المدينة الإدارية كركز إقامة الو الي "ولم تتضـح وظيفتها التجاريـة

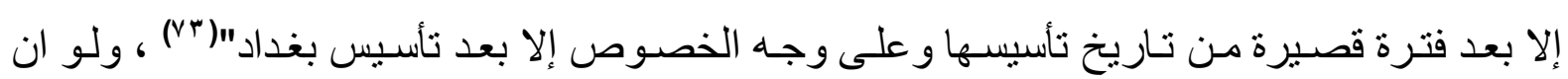
وضعها الإداري صـار بعد مـوت الحجاج أقل أهمية عمـا كانت عليه في حياته حيث أنها كانت تقوم بوظيفة العاصمة( ؛ (v) . وقد جاءت تلك النظرة من قبل الحجاج بعد اكتسابه خبرة إداريـة من جر اء تنقله حينما كان يتنقل بين البصرة والكوفة وعرف مضـار ازدواجيـة الإدارة "لذلك عول على اختيار هذا

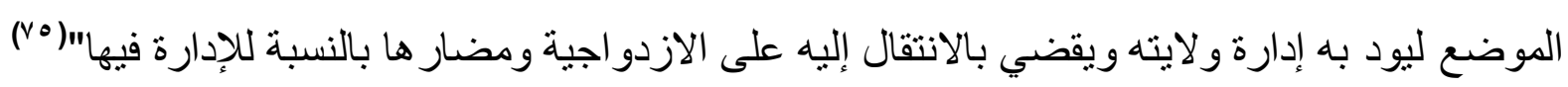
ـ وكما ويتضح كذلك دور واسط الإداري في وقو عها بين دجلة و الفرات حيث أن وقوع دجلة على شرق و اسط و الفرات في غربها(" آميجعل منها منطقة إدارة ممتازة لمدن و أطر اف العراق . أما عاملها العسكري فيأتي بالدرجة الأسـاس من التحصين الذي وضعه الحجاج لمدينته ، ولم يكن ذلك التحصين موجـوداً في المصـرين البصـرة والكوفـة ، وولا ننسىى ان الحجـاج تعرضـت حياتـه للخطر في ثورة ابن الجارود حين زحف عليه ومعهُ اتباعه ونهبو ا فسطاطه وأخذو ا مـا قدروا عليه من متاعه ودو ابـه وجـاء "أهل اليمن فأخذو امر أتـه ابنـة النعمـان بـن بشـير وجاءت مضـر فأخذوا امر أتـه 


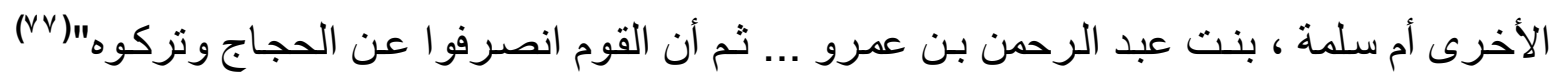

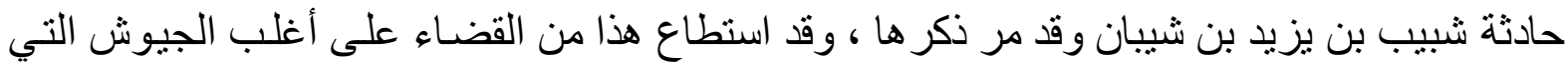

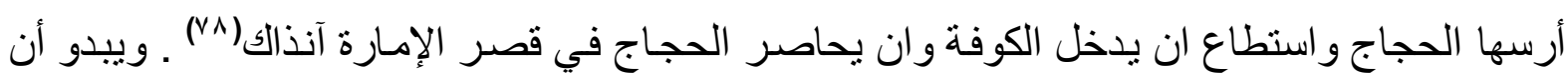
قصر الإمارة وتحصينه هو ما أنقذ الحجاج من مصيرٍٍ محتوم وليس من المستبعد ان فكرة تحصين و واسط الهبها تحصين ذلك القصر (أي قصر الإمارة) ـ ان البصرة و الكوفة لم تكن من المدن المحصنة

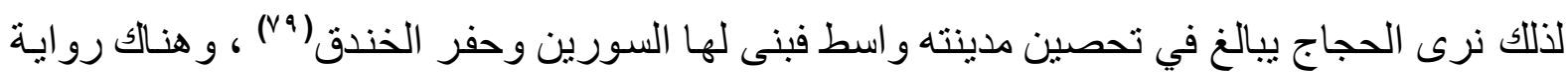

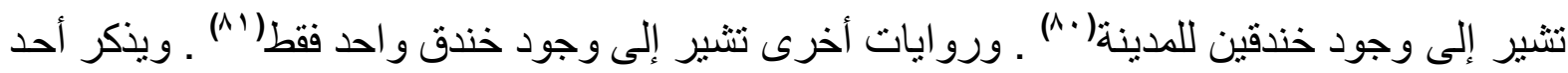

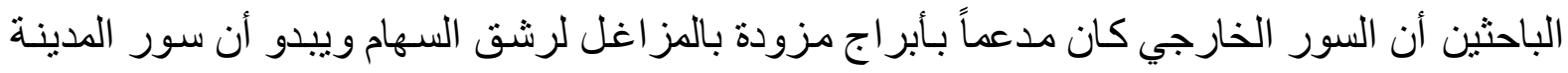

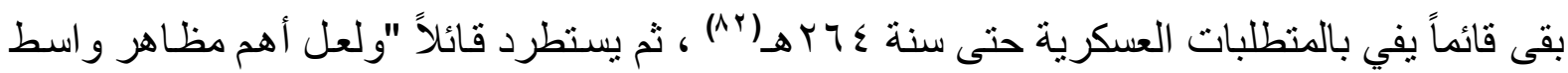

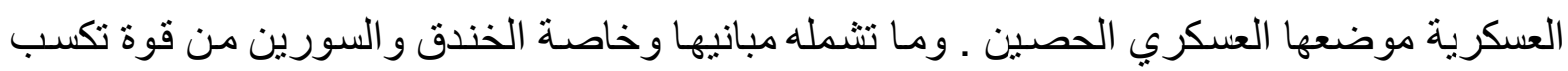

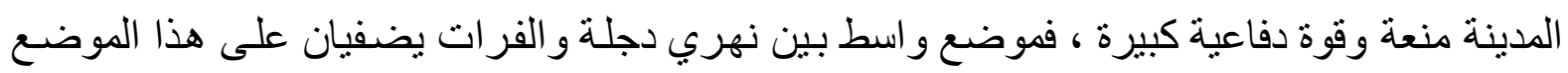
أهمية عسكرية مميزة إذ يصعب على المهاجمين للمدينة التو غل لهحاصرة واسط إذا ما قطعت الجسور

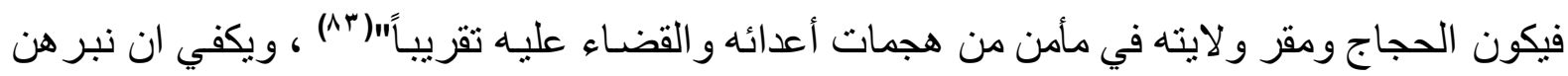
إلى قوة وحصانة المدينة إلى حادثة مهمة ، رغم أنها حصلت بعد وفاة الحجاج بسنين لكنها تدلل وتؤكد

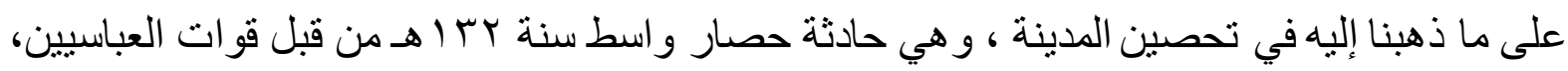

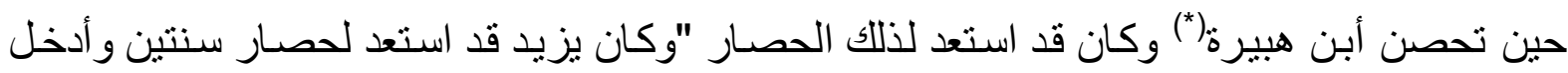

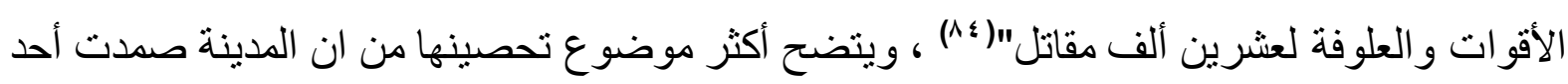

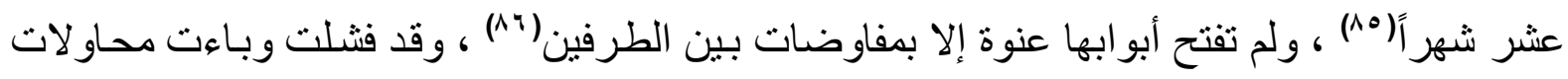

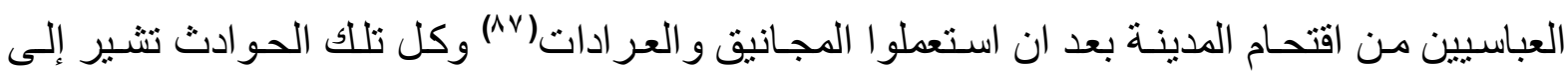

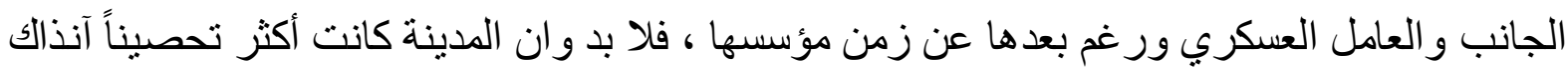

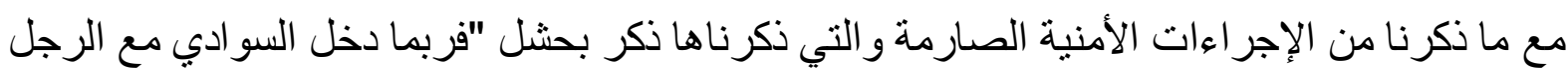

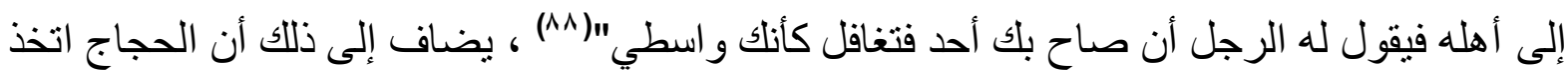
المناظر بينهُ وبين قزوين وكان إذا دخن أهل قزوين دخنت المناظر ان كان نهار أ وان كان ليلاً أثنعلوا

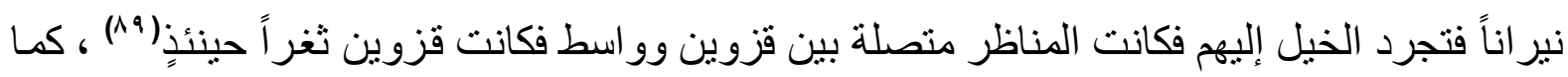

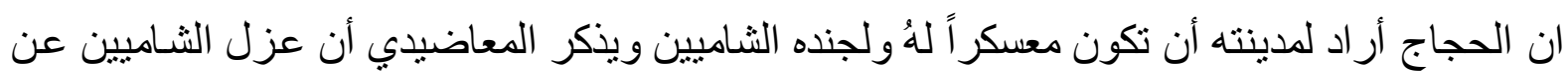
سكان البصرة و الكوفة جاء لأن سكان هؤلاء الددن كانوا من أخلاط الناس و لأنهم كانوا يعتنقون أفكار أ

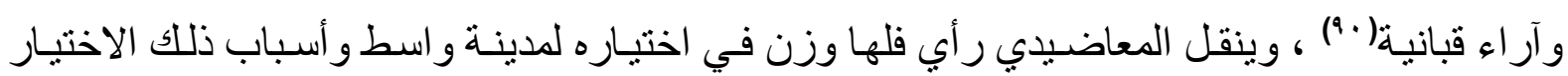

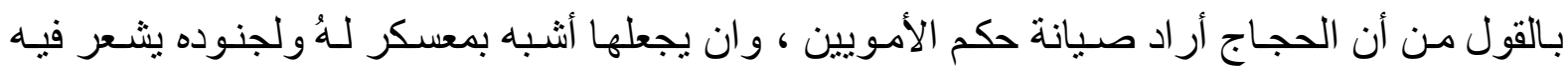


بالاطمئنـان( (9) ، وفي الاعتقاد أن مـا ذكرنـاهُ حول العامـل العسكري أو جانب و اسط العسكري يكفي للتدليل على أسباب اختيار ها من هذا الجانب .

عامل أخر وهو لا يقل أهمية عن العوامل الأخرى ، وهو العامل أو الجانب الطبيعي والصحي في المدينـة أو في اختيـار المدينـة حيـث أر اد الحجـاج لمدينتـهِ ان تتـوفر فيهـا العو امـل الصـحية تجنبـاً للأمر اض و الأوبئة ، فالمنطقة كما ذكرنـا كانت منطقة بطـائح أي منطقة أهوار ، وحين أراد الحجـاج اختيار موقع المدينة قال لرجل من ثقاته "أمض وابتغ لي موضعاً في كرش من الأرض أبني فيه مدينة

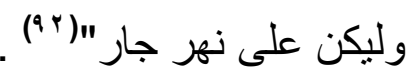

وينقل الحموي كذلك روايـة عن الاصمعي من ان الحجـاج وجها الأطبـاء ليختارو اللهُ موضـعاً حتى يبني فيه مدينة فذهبوا يطلبون ما بين عين التمر (*) إلى البحر وجولوا العراق ورجعو ا وقالوا مـا أصبنا مكاناً أوفق من موضعك هذا في خفوف الريح و أنف البرية وكان الحجاج قبل اتخاذه واسطاً أراد

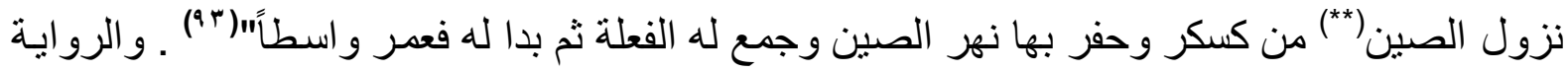
تشير إلى ان الحجـاج اختار موضـع واسط أولاً ثم أرسل الأطباء لاختيار موضـع أصلح منـه أو أكثر

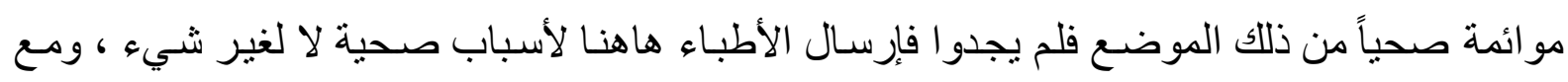

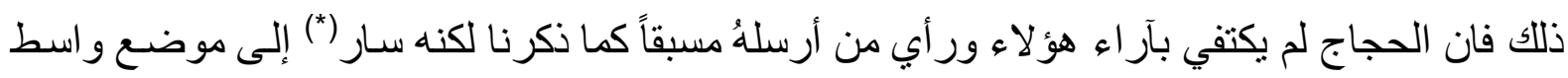
"فبات بها واستطاب ليلها و استعذب أنهار ها واستمر أ طعامها وشر ابها فقال كم بين هذا الموضع و الكوفة فقيل للهُ أربعون فرسخاً قال فإلى المدائن قالو أربعون فرسخاً قال فإلى الأهو از قالو أربعون فرسخاً قال

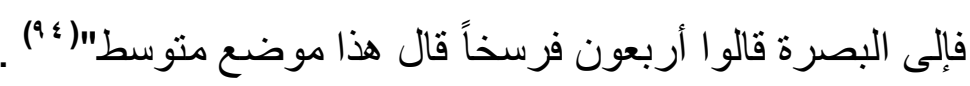
كما أن الحجاج بنى مدينته كما ذكرنا في كرش من الأرض "أي في منطقة مرتفعة لتحقق للهُ ظروف مناخية وصحية باعتبار ان هذه المنطقة هي منطقة أهوار. و أنهُ فرض ان تكون على نهر جارِ

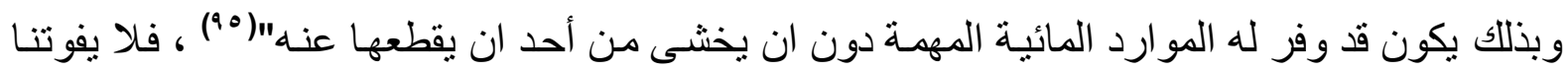

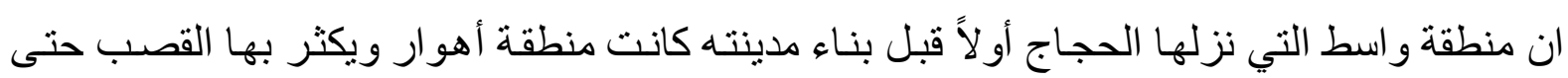
سميت بواسط القصب(ז9) ، فكانت المياه المحيطة بها من دجلة والفرات توفر مصادر الثرب والإرواء وتصريف المياه منها ، كما أنها كانت كما وصفها المقدسي "سهلية جبلية برية بحرية"(va) ، وأثار إليها ابن حوقل بالقول "ومدينة و اسط على جانبي دجلة تشقها بنصفين ... و هي مدينة تحيط بحدها الغربي البادية بعد مز ارع بسيرة وهي خصبة كثيرة الشجر و النخل و الزرع ، و أصح هو اءً من البصرة وليس بها بطائح ولها أرض و اسعة ونو اح فسيحة و عمارة متصلة"|(^^)، ، ان هذه الخصـائص من أرضٍٍ سهلية

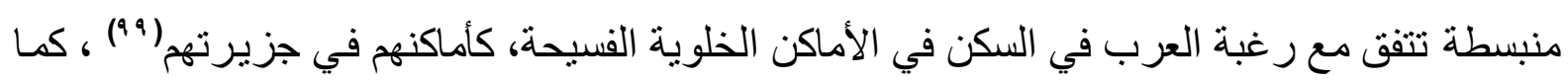


ان شق الأنهار و التشجير و المزارع التي أوجدها الحجاج والأمر اء الذي تو الوا على حكم واسط كان لـهُ كبير الأثر في تلطيف هو اء المدينة ، وتجفيف البطائح( '.").

ونذكر نصاً طريفاً في نقد الحجاج لمدينتي البصرة والكوفة و أنهُ أراد لو اسط أن تكون أحسن من

تللك المدينتين كما يقول أحد الباحثين ، حيث ذكر الحجاج "أما البصرة فعجوز شمطاء بخر اء(*) دفر اء(*)

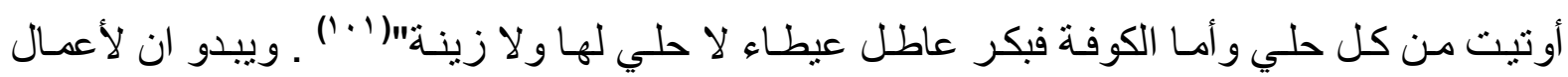
الحجاج ومن جاء من بعده أثرهُ في عمارة مدينة و اسط وتقدمها حتى ذكر ها الحموي "ور أيت أنـا واسطاً مر اراً فوجدتها بلدة عظيمة ذات رسـاتيق وقرى كثيرة وبسـاتين ونخيل يفوت الحصر وكان الرخص وهل

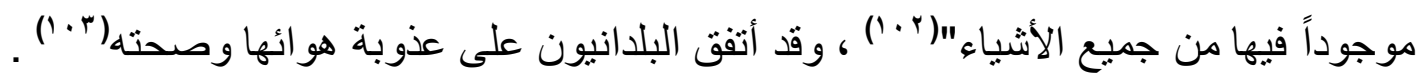

| الغاتمـــــة

بنـاء و اسـطـ مـن الأمسور المهــة في تـاريخ العراق أن لـم يكن حتى في تـاريخ مدن المشـرق الإسـلامي فقد لعبـت هذه المدينـة أول أمر هـا دوراً سياسياً وعسكرياً وإداريـاً تمثنل في كونهـا أنشـئت لأغر اض غير الأغر اض التي أنشأ العرب مدنهم لهاوقد خلصت هذه الدراسـة إلى أمور منها أن وسط وموقعها تم اختيار هم بدقة بدايةً من حصانتها الطبيعية كمنطقة تحيطها الأنهار دجلة و الفر ات مما وفر للمدينة خندقاً مائياً طبيعياً يصعب اختر اقهُ من جهة ووفر الماء و الطعام (السمك) من جهة أخرى كما ان بناء المدينة (المدور) سبق بناء بغداد و هي جزء من حصانة المدينة التي ذكر ها البلدانيون أنها في مكان

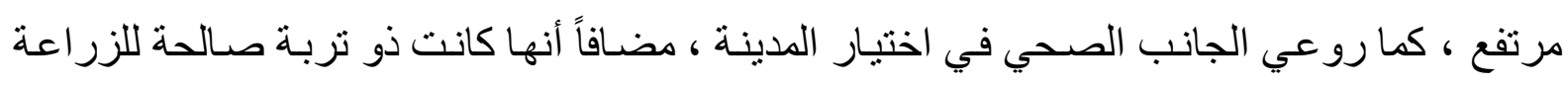
و هو ما جعل الحجـاج يستثمر أرضها حتى غدت من بعده مدينة كثيرة الزروع بعد ان كانت أرضها أرض بطائح يكثر فيها القصب حتى كانت تسمى قبل بنائها بو اسط القصب كما ذكر ، كما أن للموقع الحيوي أثرهُ الذي ظهر لسنين طويلة بل ولوقتنا الحاضر في استمرار وديمومة تلك المدينة رغم انتفاء الغرض الذي بنيت لأجله . كما أثبتت الحصانة والمنعة التي تمتعت بها عند حصسار العباسبين لها عام بT ا هـ عندما تحصن بها ابن هبيرة ولم يستطع العباسبون دخولها عنوة لحصانة أسوار ها ولمنعتها الطبيعية.

الهواهش

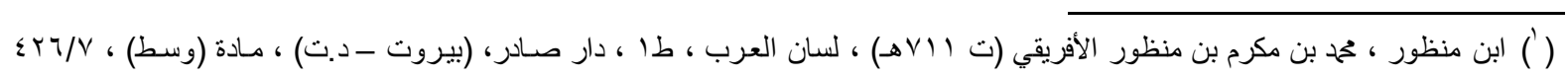

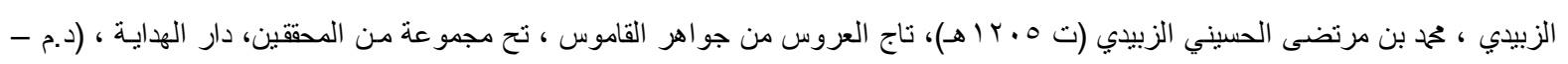

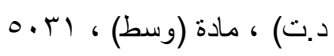

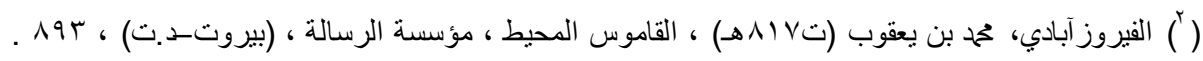

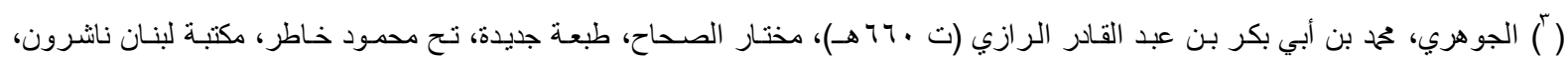

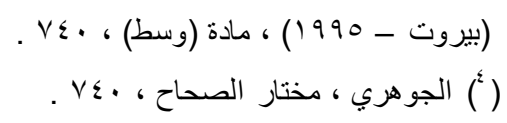




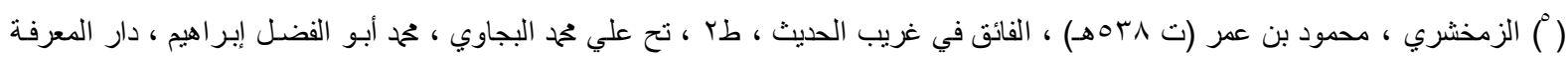

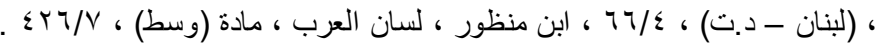

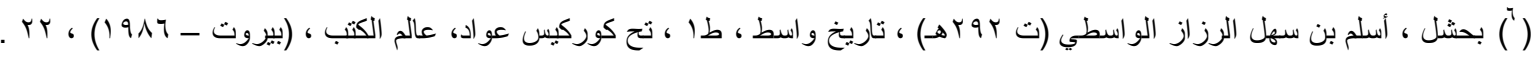

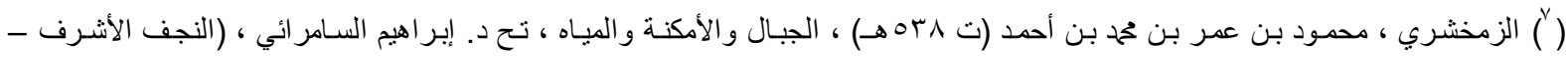

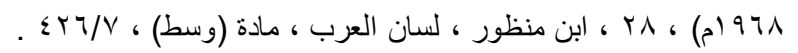

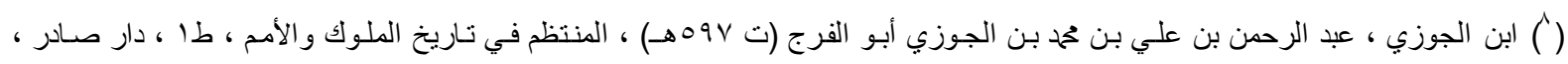

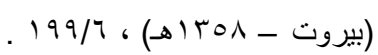

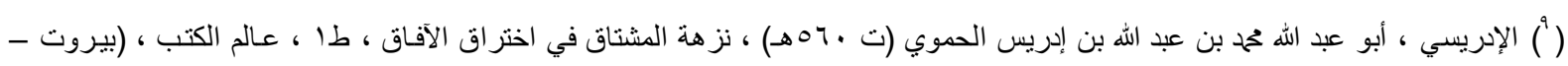
. $777 / r .(1919$

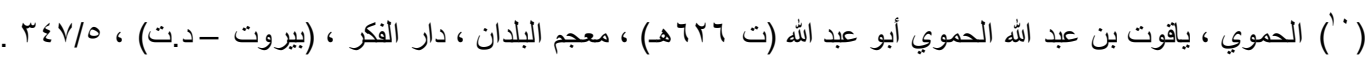

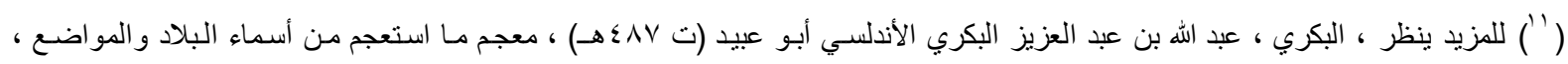

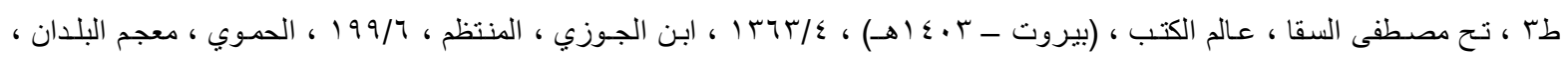

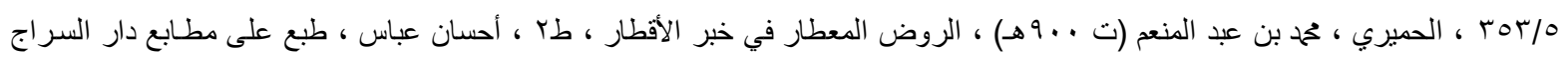

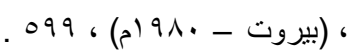

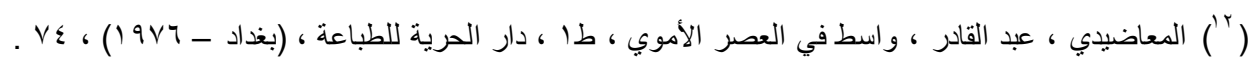

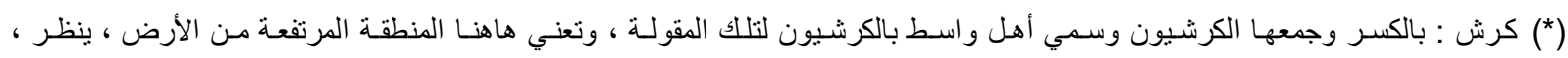

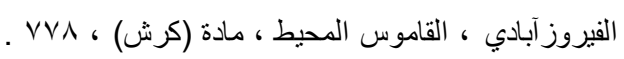

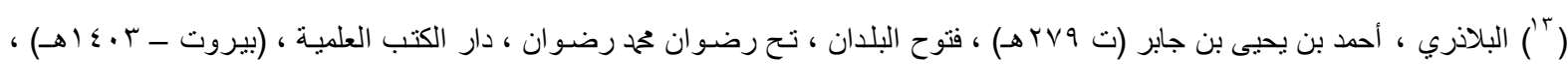

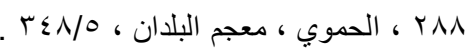

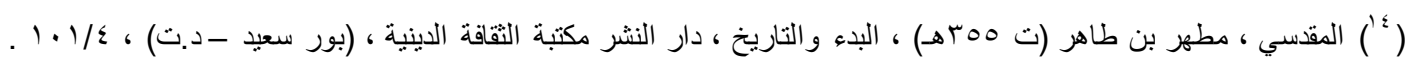

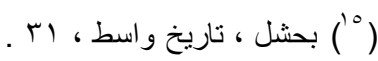

(*) ذكر ابن كثير ان الحجاج حبس أعر ابي وجده يبول في أصل ريض مدينـة واسط ثم أطلقهُ فر اح الأعر ابي يقول : إذا نحن جاوزنـا مدينـة

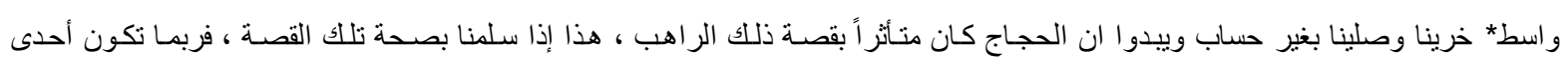

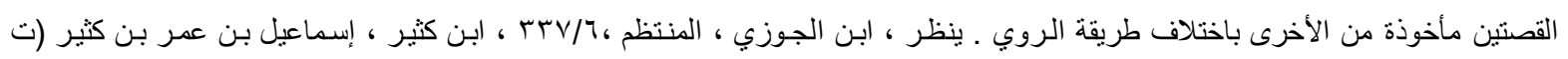

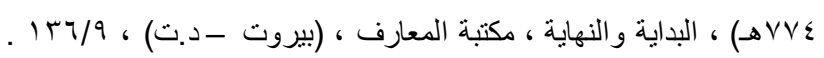

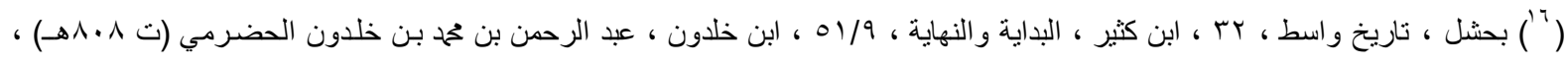

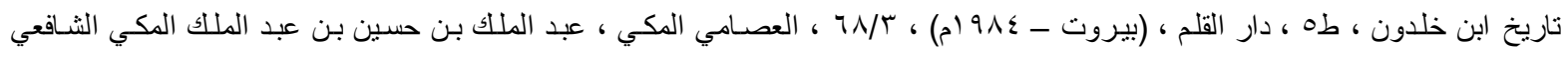

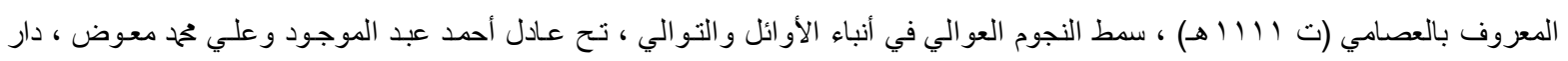

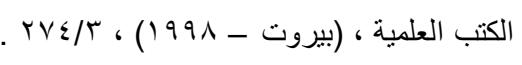

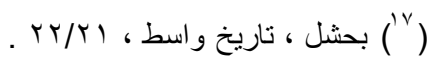

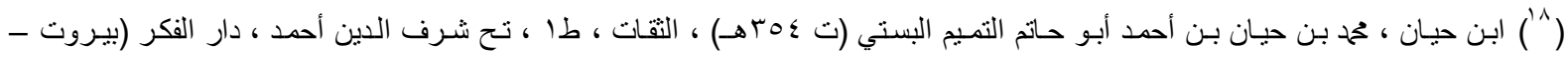

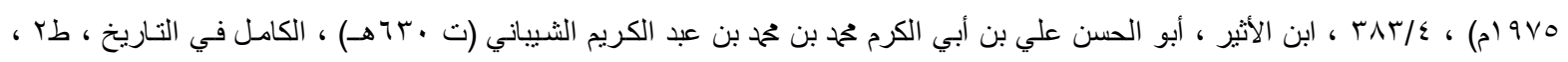

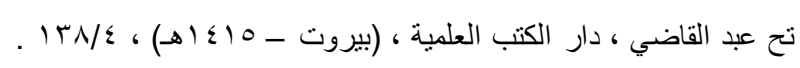

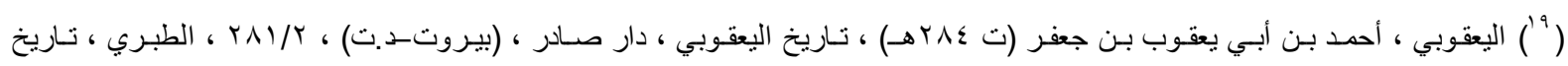
الطبري ، سر/. ror.

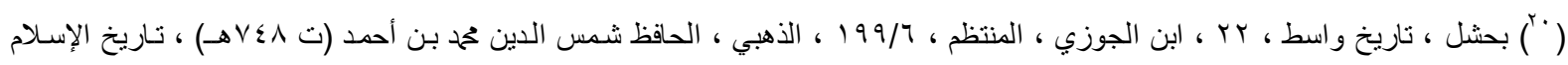

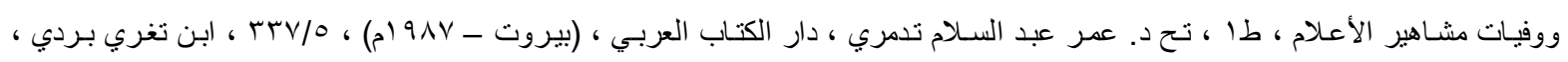

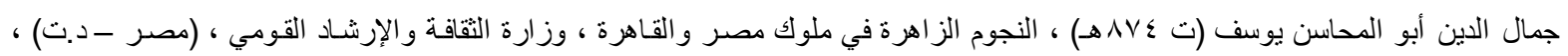




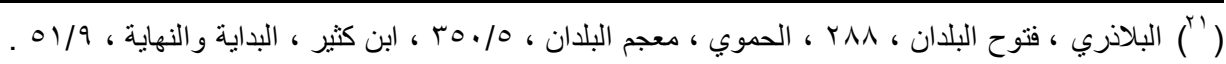

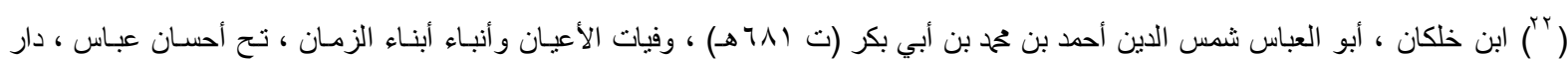

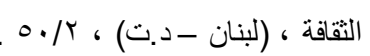

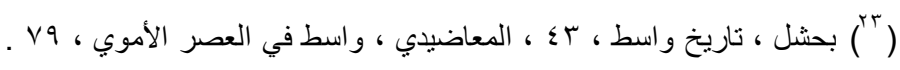

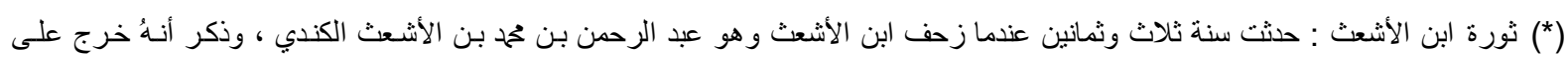

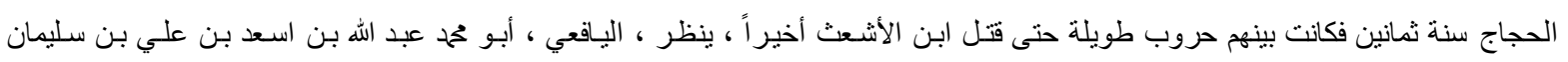

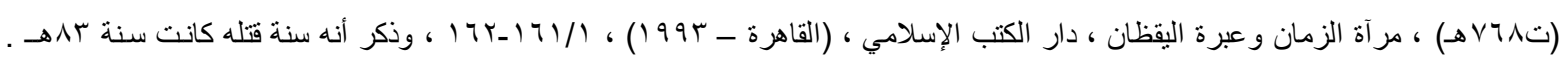

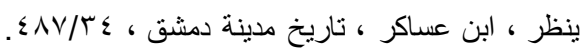

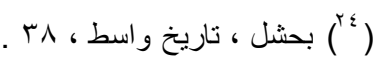

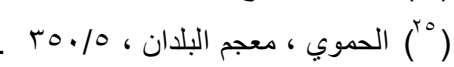

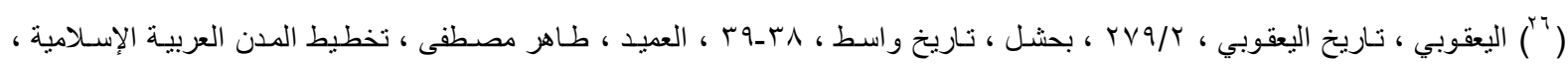

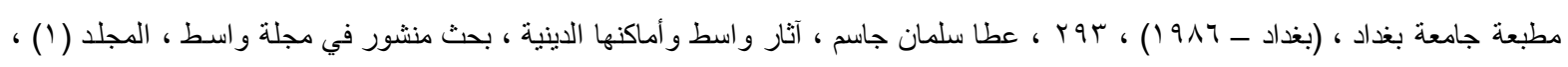

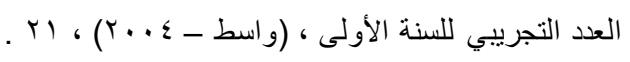

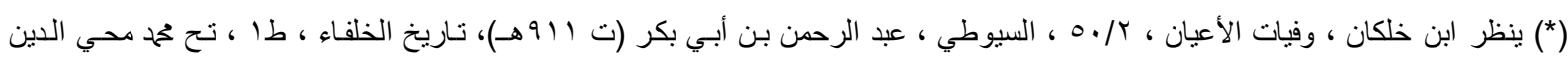

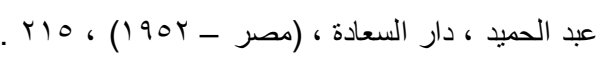

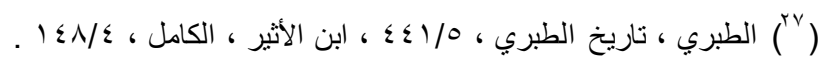

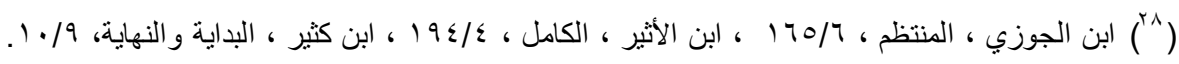

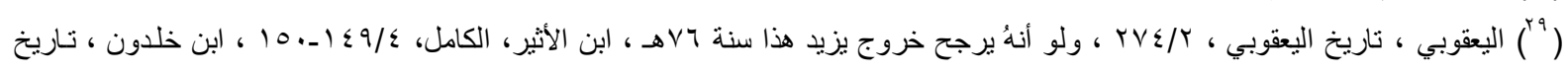
$.19 \cdot / 4$ ،

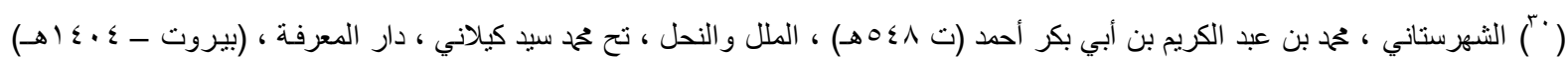
$.1 \mathrm{r} / 1$ ،

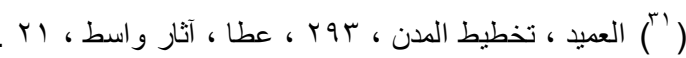

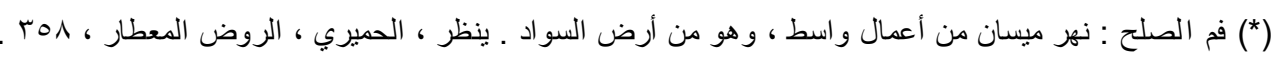

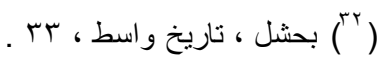

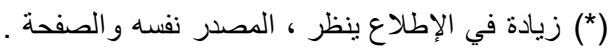

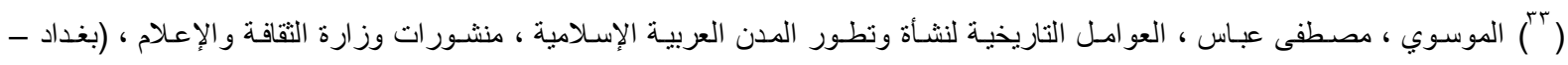
.110 ، (1914

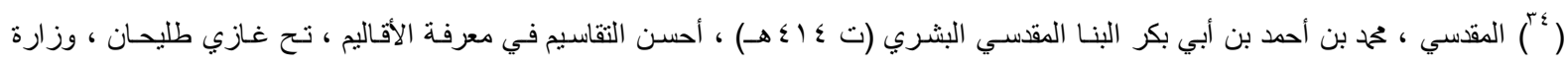

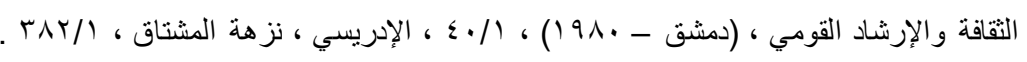

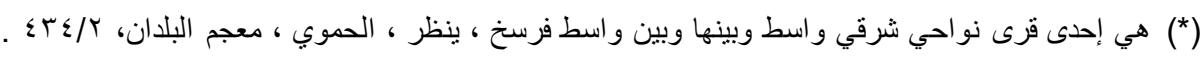

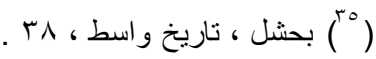

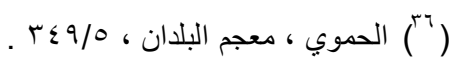

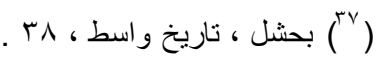

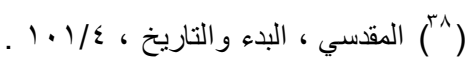
( ) (

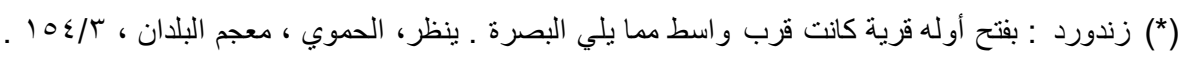

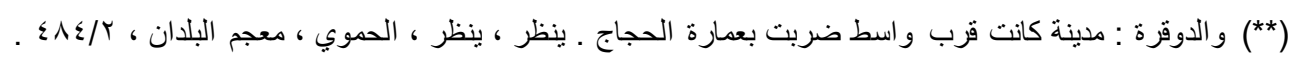

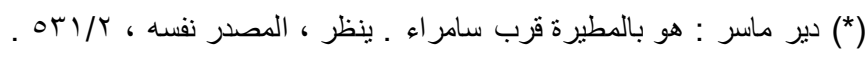

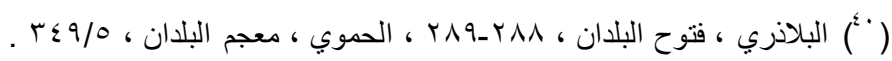

\section{-INH.}


(**) يرى الأستاذ جرجي زيدان ان بناء القبة وتلوينها باللون الأخضر إنما كان محاولة لجماع السلطة الدينية مع السياسة بأيديهم كما فعلوا عندما

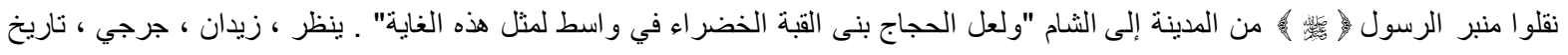

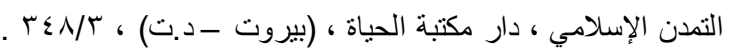

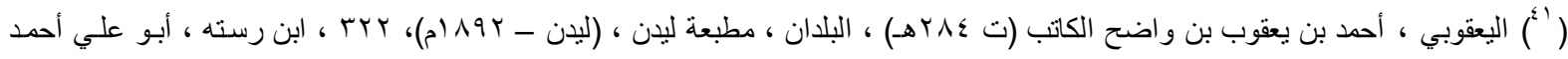

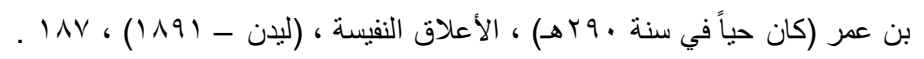

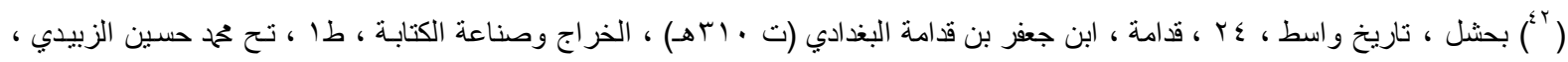

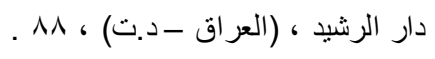$$
\text { ( ) ( })
$$

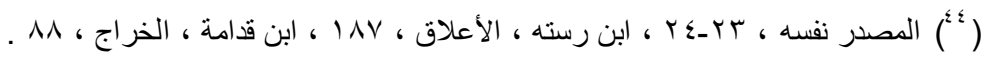

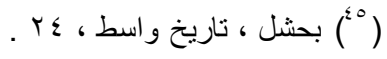

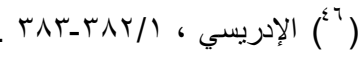

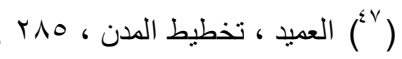

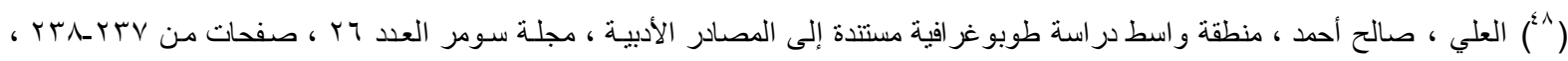

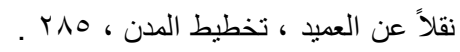

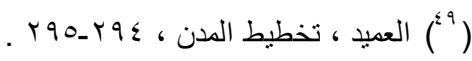

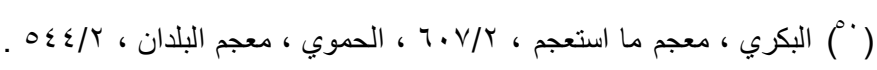

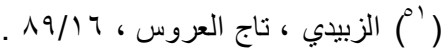

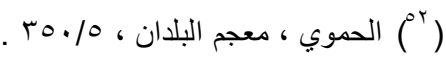

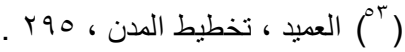

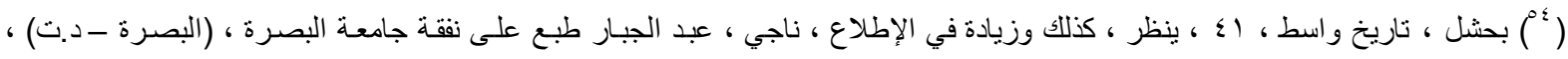

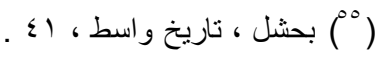

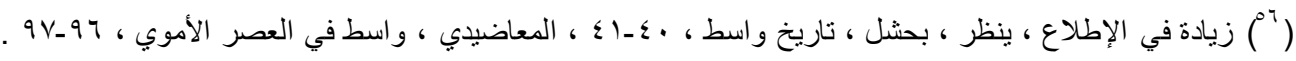

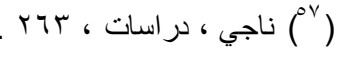

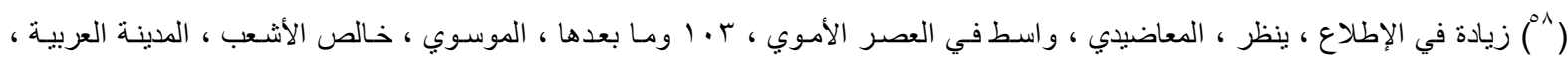

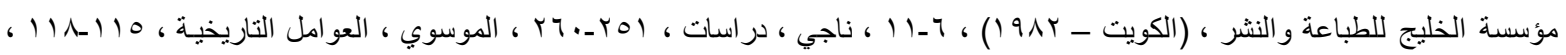

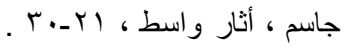

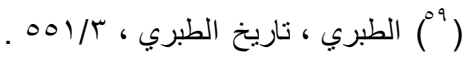

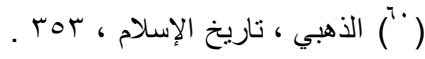

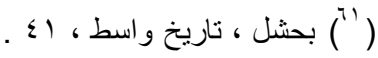

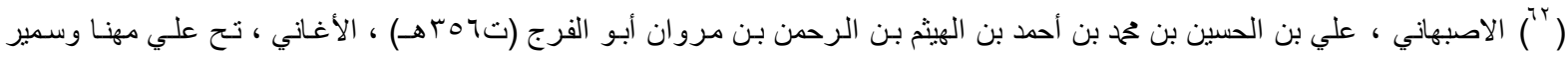

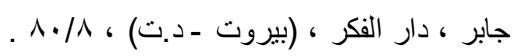

$$
\begin{aligned}
& \text { (") }
\end{aligned}
$$

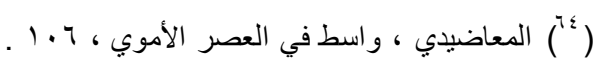

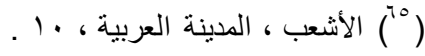

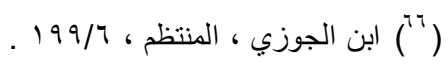

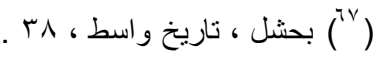

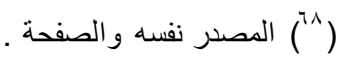

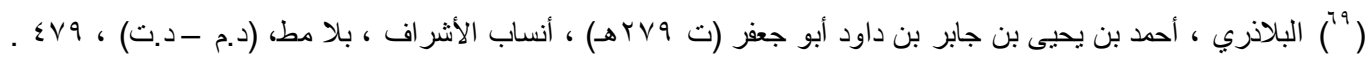

\section{$-1 \wedge \varepsilon$.}




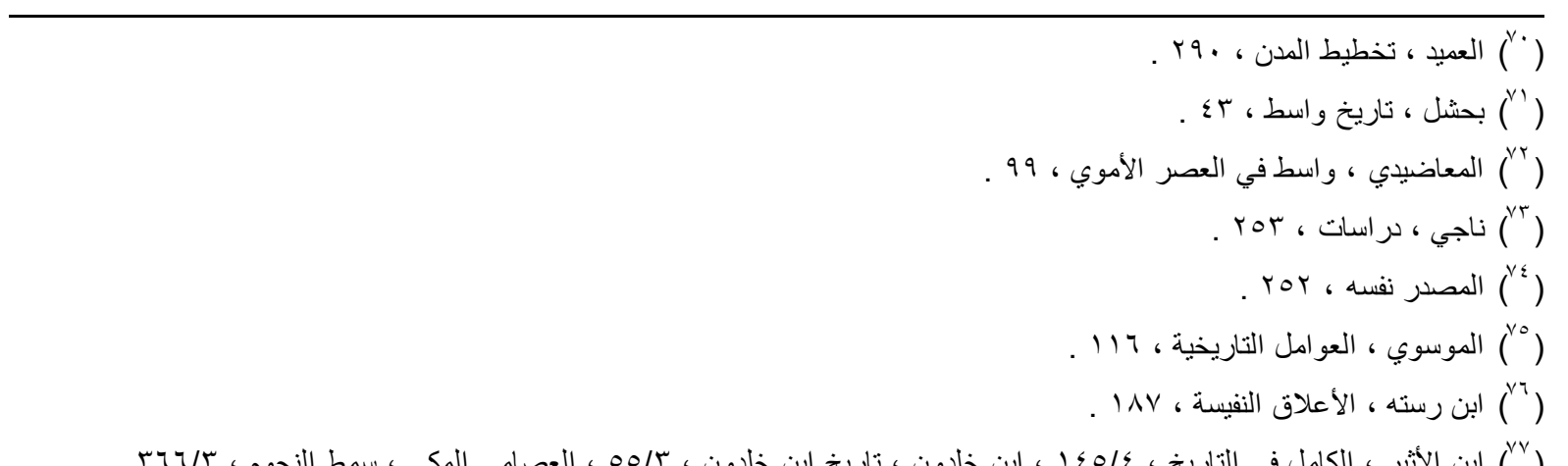

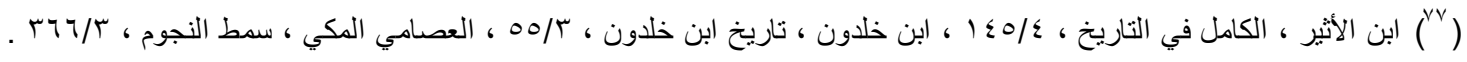

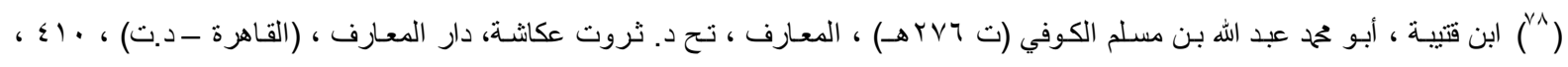

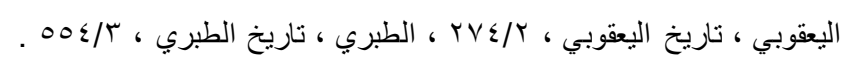

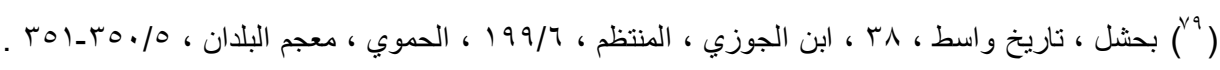

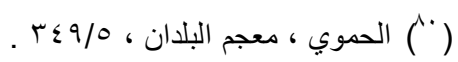

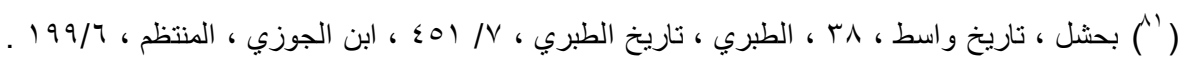

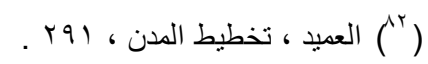

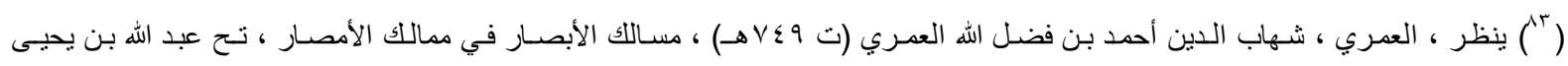

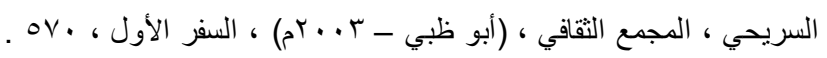

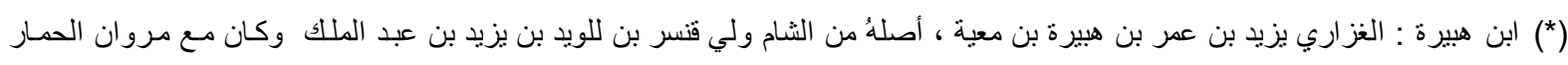

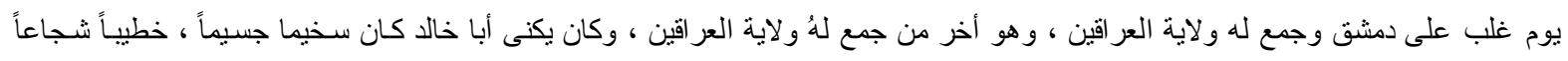

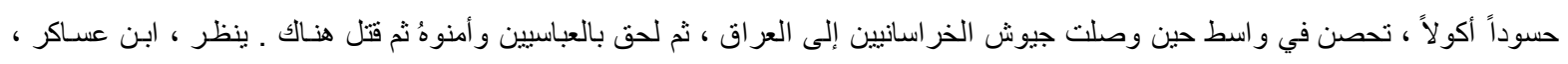

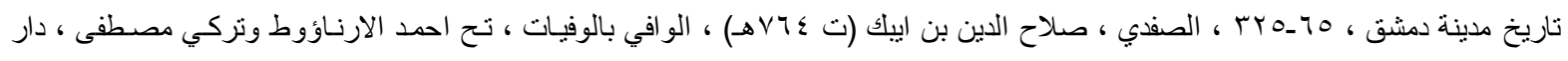

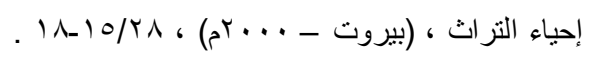

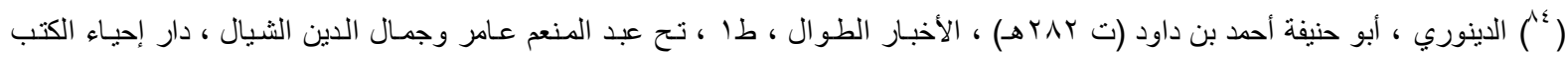

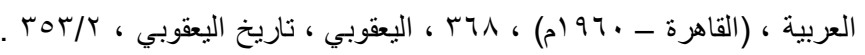

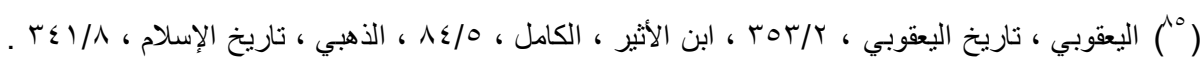

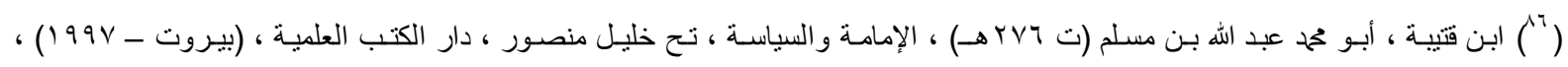

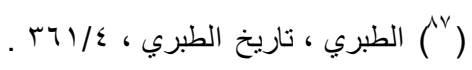

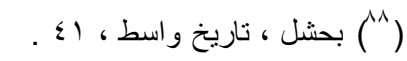

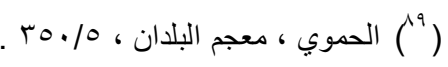

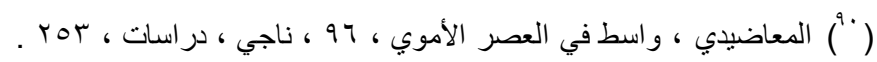

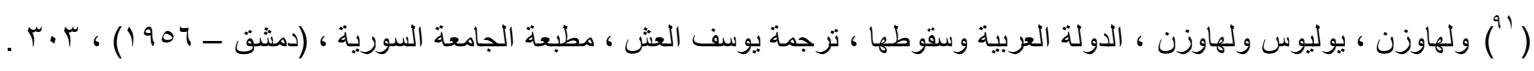

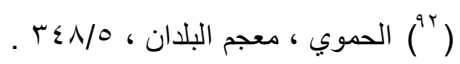

(*) عين التمر : بلدة قريبة من الأنبار غربي الكوفة ، الفتحها المسلمون في أيام أبو بكر على يد خالد بن الوليد ـ الحموي ، معجم البلدان ، . $117 \% / \varepsilon$

،* الصين : على لفضة الصين بلاد الهشرق المعروفة وهي رستاق من كسكر و هما رستاقان يقال لهما الصين الأعلى و الصين الأسفل ـ ينظر

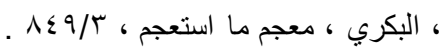

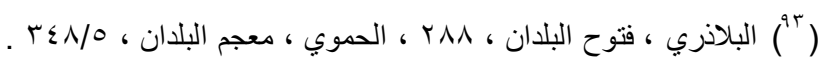

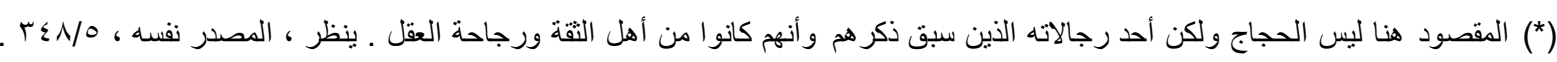

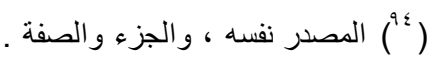

\section{$-110-$}




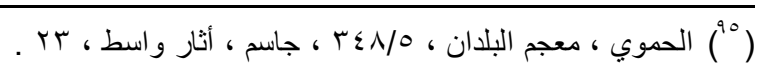

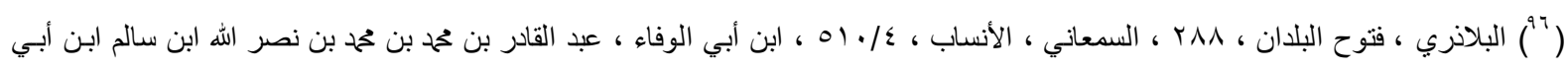

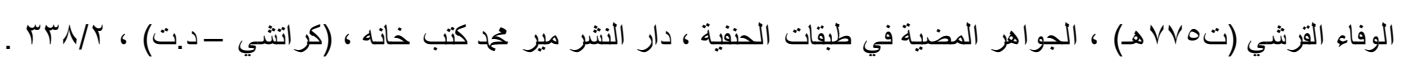

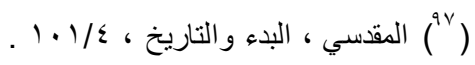

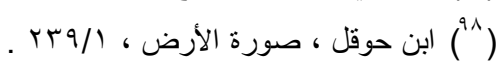

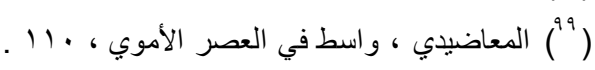

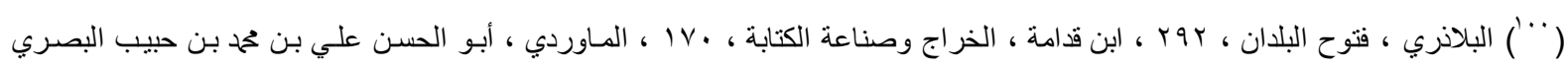

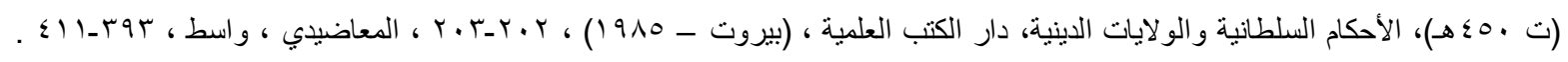

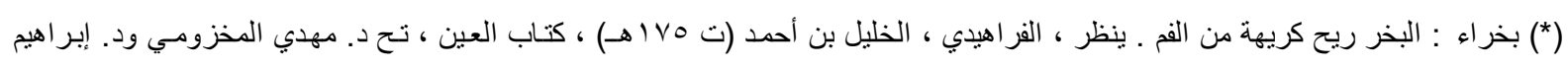

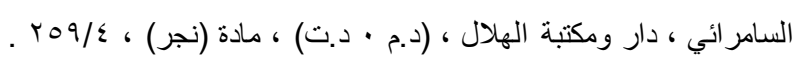

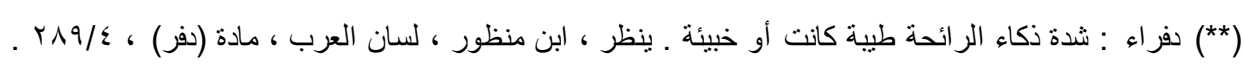

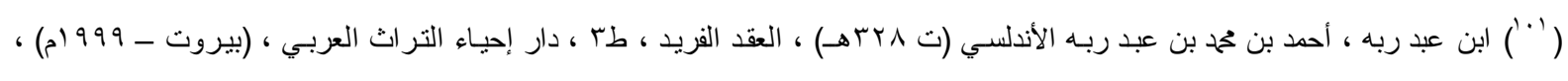

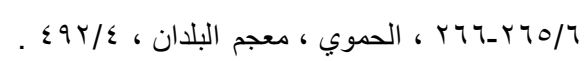

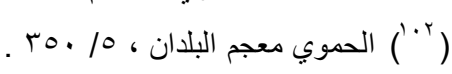

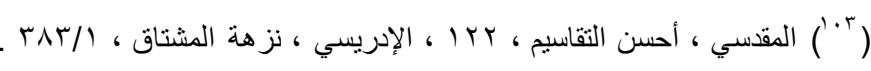

\section{المادر والمراجع}

ابن الأثير ، أبو الحسن علي بن أبي الكرم ححمد بن محمد بن عبد الكريم الثيباني (ت . با7هـ) ، الكامل في التاريخ ، طب ، تح عبد القاضي ، دار

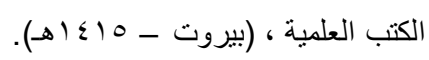

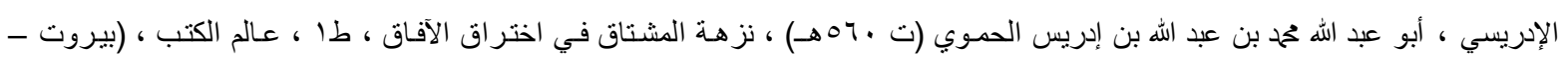

.(1919

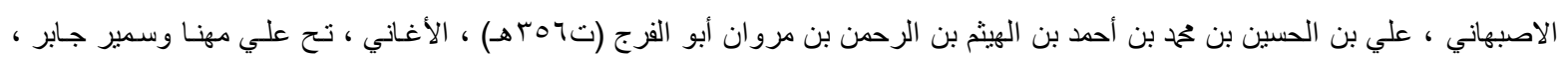

$$
\text { دار الفكر ، (بيروت - د.ت). }
$$

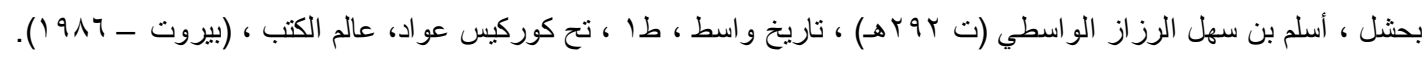

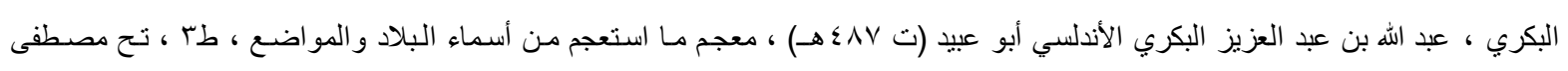

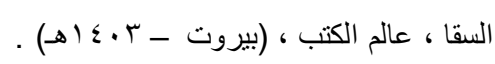

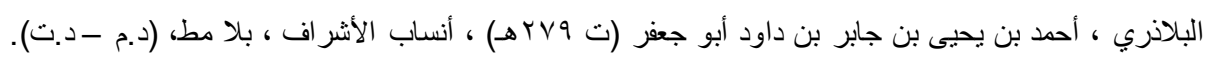

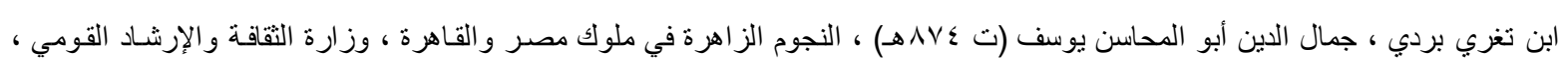

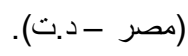

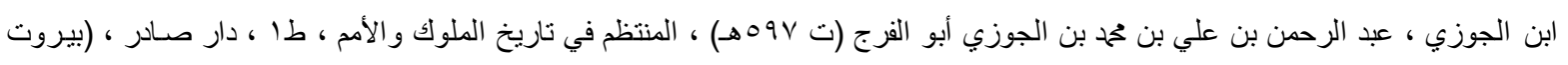
. (1) (1) الجوهري ، محمد بن أبي بكر بن عبد القادر الر ازي (ت . 77هـ) ، مختار الصحاح ، طبعة جديدة ، تح محمود خـاطر ، مكتبة لبنـان ناشرون ، (بيروت - (ب90 (1990)

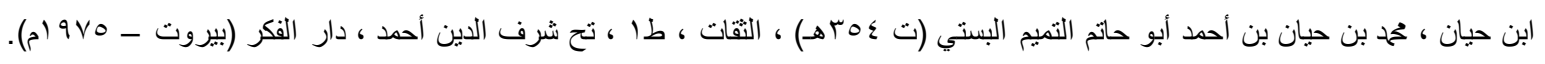

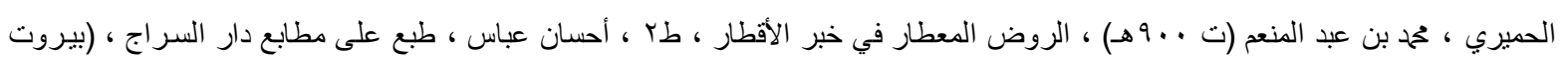

. (م) $91 \cdot-$ الحموي ، ياقوت بن عبد الله الحموي أبو عبد الله (ت 7r 7 هـ) ، معجم البلدان ، دار الفكر ، (بيروت - د.ت).

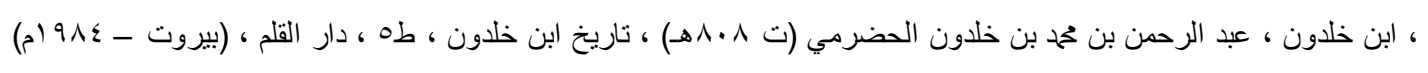

\section{$-117$.}




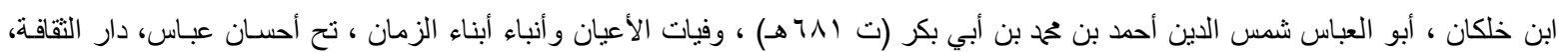

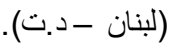
الدينوري ، أبو حنيفة أحمد بن داود (ت Y Y Y هـ) ، الأخبار الطوال ، طان ، تح عبد المنعم عامر وجمال الدين الثبال ، دار إحياء الكتب العربيـة

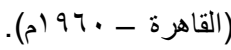

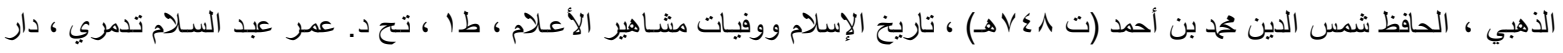

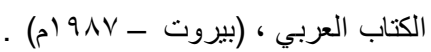

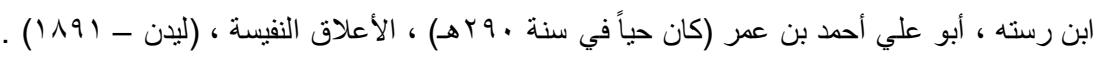

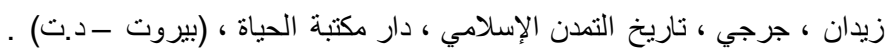

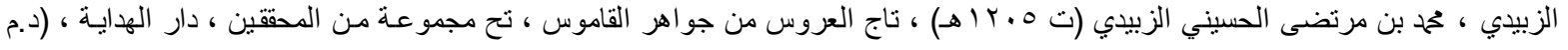
.د. (ت.د-

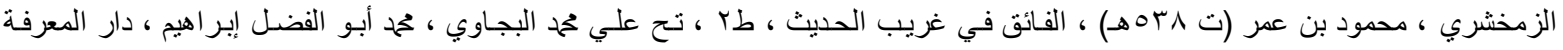

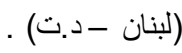

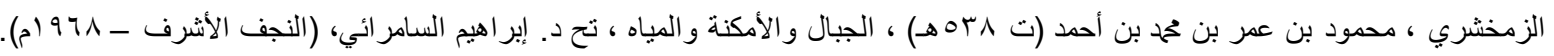

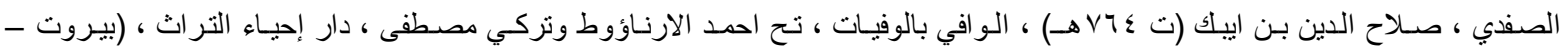
. (5)...

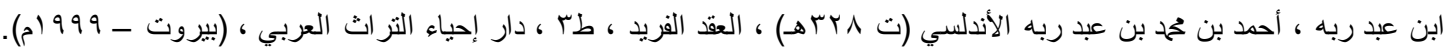

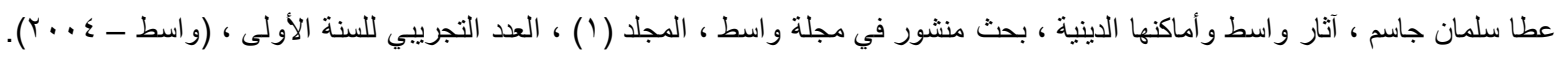

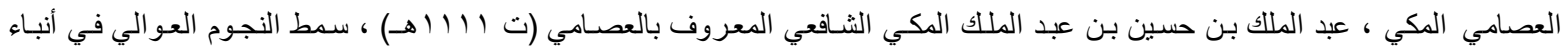

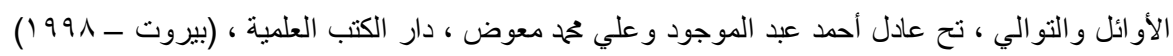

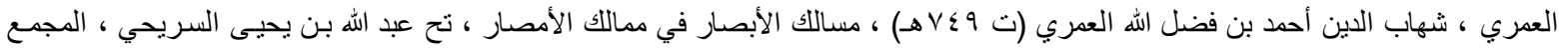

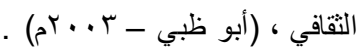

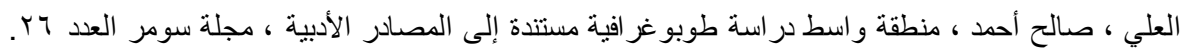

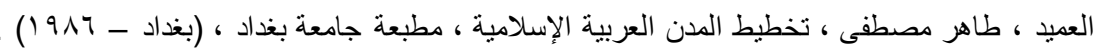

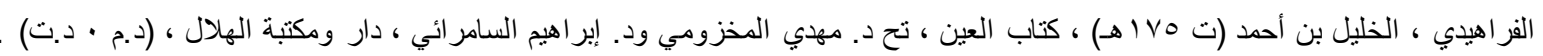

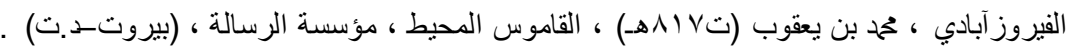

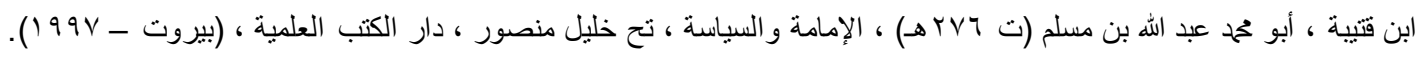

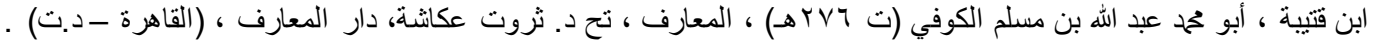

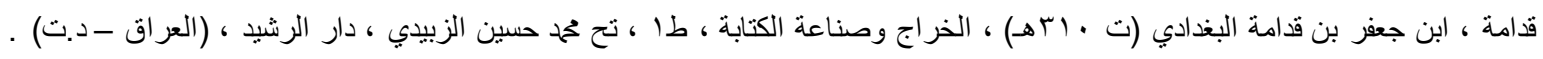

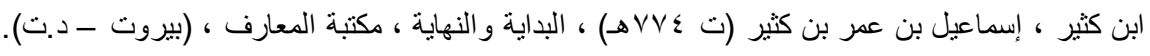

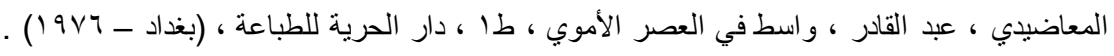

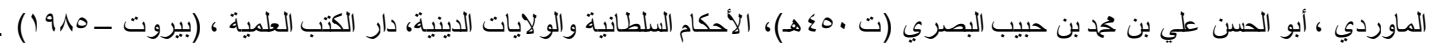

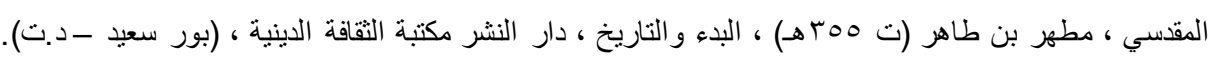

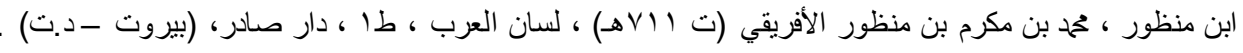

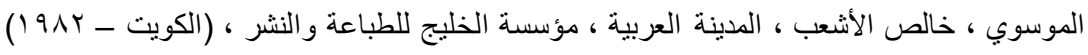

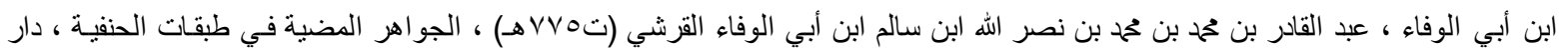
النشر مير محمد كتب خانه ، (كر اتثي - د.تث).

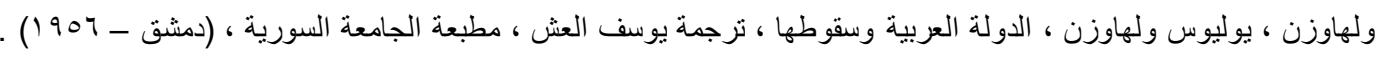

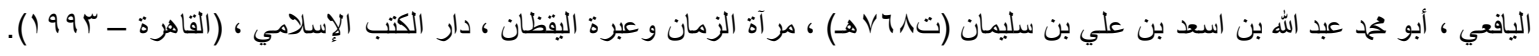

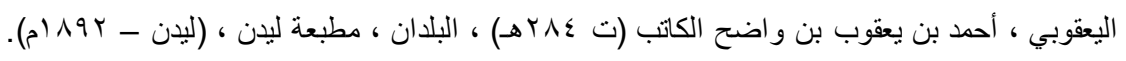

